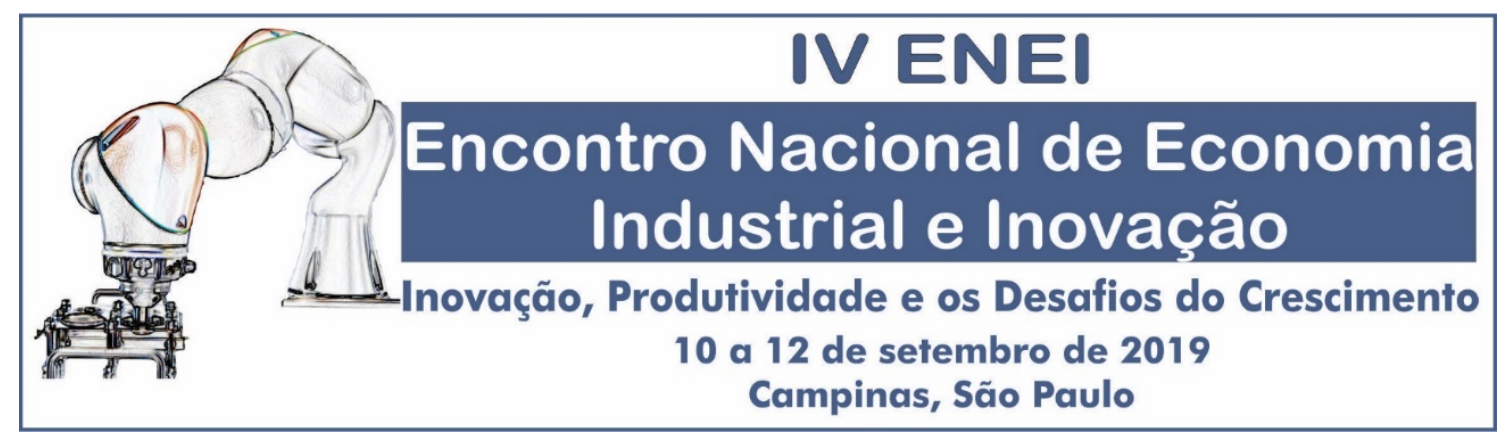

\title{
Inovação por intensidade tecnológica, cooperação e origem do capital
}

\author{
Milene Simone Tessarin ${ }^{\mathrm{a}}$; Wilson Suzigan ${ }^{\mathrm{b}}$; Joaquim José Martins Guilhoto ${ }^{\mathrm{c}}$
}

\begin{abstract}
Resumo
Este artigo analisa o esforço inovativo das empresas manufatureiras que cooperaram para inovar e das que inovaram sem cooperação, segmentadas por categorias tecnológicas e origem do capital controlador. Utilizou-se uma tabulação especial da Pintec/IBGE com informações inéditas. O estudo contribui ao contrapor empresas que inovaram com e sem cooperação, pois esta comparação ainda não foi estudada. Resultados mostraram que a cooperação é decisiva para diferenciar os esforços inovativos, independente da categoria tecnológica. Já a origem do capital não representou fator distintivo. A cooperação foi essencialmente feita com clientes e fornecedores, e outra empresa do grupo no exterior para firmas estrangeiras, a despeito da literatura focar na cooperação com universidades e institutos de pesquisa. Conclui-se que inovar com cooperação gera esforços inovativos melhores, assim, estimular empresas a cooperarem pode aumentar a inovação brasileira.
\end{abstract}

Palavras-Chave: Inovação; Cooperação para inovar; Indústria de transformação; Intensidade tecnológica; Desenvolvimento industrial.

\section{Innovation by technological intensity, cooperation and origin of capital}

\begin{abstract}
This article analyze the innovative effort of the manufacturing companies that cooperated to innovate from those that innovated without cooperation, segmented by technological categories and origin of controlling capital. Special data with information's from Pintec/IBGE has been used. The contribution is contrasting companies that innovated with and without cooperation, since this comparison has not yet been studied. Results showed that cooperation is decisive to differentiate innovative efforts, regardless of the technological category. The origin of controlling capital did not represent a distinctive factor. The cooperation was mainly made with customers and suppliers, and another group company overseas to foreign firms, despite the literature focus on cooperation with universities and research institutes. It is concluded that innovating with cooperation generates better innovative efforts, thus, stimulate companies to cooperate can increase Brazilian innovation.
\end{abstract}

Keywords: Innovation, Cooperation to innovate; Manufacturing; Technological intensity; Industrial development.

Códigos JEL: O32; P13; L10.

Área ABEIN: 4.4 - Redes de inovação: alianças de P\&D, interações universidade-empresa, outras redes.

\footnotetext{
a Doutora em Economia pela FEA-USP. Email: milene.tessarin@gmail.com. A autora agradece o apoio da Capes e da Fipe.

${ }^{\mathrm{b}}$ Professor Colaborador do Departamento de Política Científica e Tecnológica (DPCT), Instituto de Geociências/Unicamp.

${ }^{c}$ Economista da OCDE e professor da USP. O conteúdo dessa publicação expressa a visão deste autor e não necessariamente representa a visão da OCDE ou dos seus países membros.
} 


\section{Inovação por intensidade tecnológica, cooperação e origem do capital}

\section{Resumo}

Este artigo analisa o esforço inovativo das empresas manufatureiras que cooperaram para inovar e das que inovaram sem cooperação, segmentadas por categorias tecnológicas e origem do capital controlador. Utilizou-se uma tabulação especial da Pintec/IBGE com informações inéditas. O estudo contribui ao contrapor empresas que inovaram com e sem cooperação, pois esta comparação ainda não foi estudada. Resultados mostraram que a cooperação é decisiva para diferenciar os esforços inovativos, independente da categoria tecnológica. Já a origem do capital não representou fator distintivo. A cooperação foi essencialmente feita com clientes e fornecedores, e outra empresa do grupo no exterior para firmas estrangeiras, a despeito da literatura focar na cooperação com universidades e institutos de pesquisa. Conclui-se que inovar com cooperação gera esforços inovativos melhores, assim, estimular empresas a cooperarem pode aumentar a inovação brasileira.

\section{Introdução ${ }^{1}$}

A inovação tecnológica é um dos motores fundamentais da competição e do desenvolvimento socioeconômico (SCHUMPETER, 1911). As transformações tecnológicas introduzidas nas últimas décadas modificaram o estilo de vida das pessoas e alteraram as suas cestas de consumo. As empresas, sobretudo as corporações multinacionais, têm uma posição central na produção de inovações.

A formação da indústria de transformação brasileira contou com a presença substantiva de empresas multinacionais estrangeiras (QUEIROZ; CARVALHO, 2005). Desde a década de 1950, filiais dessas companhias se instalaram no país e lideraram o desenvolvimento produtivo e tecnológico em diversos setores relevantes, como na indústria automobilística (CASSIOLATO; MATOS; LASTRES, 2014). Atualmente, as filiais dessas empresas dividem o protagonismo, em termos produtivo e inovador, em vários setores manufatureiros com as empresas de capital nacional. Entretanto, a posição do Brasil no desenvolvimento tecnológico mundial ainda é relativamente fraca se comparada às nações de origem das filiais das empresas multinacionais atuantes no país (KOELLER, 2018).

Uma forma de incrementar os resultados inovativos é através da cooperação entre empresas e outros atores do sistema de inovação (SUZIGAN et al., 2009), pois permite às partes envolvidas otimizar ganhos e gerenciar melhor seus ativos, acessar recursos produtivos e técnicos distantes ou indisponíveis, trocar conhecimentos e tecnologias com outros especialistas e capacitar-se para processos mais eficientes (KLEVORICK et al., 1995).

Em 2014, conforme será mostrado neste trabalho, as empresas inovadoras brasileiras que cooperaram para inovar representaram apenas 5,6\% das empresas da indústria de transformação, porém, foram responsáveis por $62,5 \%$ dos gastos com atividades inovativas e por $71,2 \%$ da receita líquida de vendas. Esses dados deixam claro que as empresas que inovaram com cooperação possuem características especiais que merecem atenção.

No Brasil, os estudos sobre cooperação se concentram na relação entre universidades e/ou institutos de pesquisa e empresas inovadoras (CASSIOLATO; BRITTO; VARGAS, 2005; BASTOS; BRITTO, $2017)^{2}$. Como será visto as universidades não são as principais parceiras das empresas brasileiras para inovar; por isso, busca-se aqui analisar a cooperação para inovar com os vários atores do sistema brasileiro de inovação. A questão setorial também será observada - a partir das categorias de intensidade tecnológica da Organização para a Cooperação e Desenvolvimento Econômico (OCDE) -, pois as oportunidades e riscos tecnológicos para inovar diferem entre os setores manufatureiros (DOSI; PAVITT; SOETE, 1990; BRESCHI; MALERBA, 1997).

Dessa forma, o objetivo deste artigo será traçar o perfil comparativo das empresas inovadoras da indústria de transformação brasileira que cooperaram para inovar e das que inovaram sem cooperação, segmentadas por quatro categorias de intensidade tecnológica e origem do capital controlador. A análise

\footnotetext{
1 Agradecemos os comentários recebidos no I ENEI em uma versão inicial deste trabalho e as sugestões dos membros do NEREUS-USP, isentando-os de quaisquer erros remanescentes.

${ }^{2}$ Bastos e Britto (2017) fizeram uma síntese atualizada desses estudos.
} 
será feita a partir do esforço e das características que as empresas apresentam no processo de implementar as inovações no mercado. Os dados provêm de uma tabulação especial inédita da Pesquisa de Inovação Tecnológica (Pintec), elaborada pelo IBGE, para o intervalo de uma década, abrangendo os períodos de 2001-2003 e 2012-2014².

As novidades deste estudo residem, primeiro, nos dados que serão apresentados, pois eles provêm de uma combinação que permitem obter informações inéditas. Segundo, apresentam-se os resultados de empresas inovadoras que cooperam em contraposição ao grupo que não cooperou, comparação que também é raramente confrontada pela literatura. Terceiro, foram elencadas todas as opções de parceiros para cooperação, agregando valor à visão que tradicionalmente aborda apenas parcerias com universidades e institutos de pesquisa. Com isso, os resultados apresentados abordam características não publicadas sobre os esforços inovativos realizados no Brasil.

Após esta introdução, a seção 2 revisará os insumos necessários para inovação e a influência de empresas multinacionais sobre a inovação dos países hospedeiros. A seção 3 apresenta a base de dados e procedimentos metodológicos. Na seção 4 estão os resultados, que mostram o perfil das empresas inovadoras no Brasil, os sete parceiros utilizados na cooperação, as 14 fontes de informação consultadas para inovar e uma síntese dos esforços inovativos bastante detalhada para cada um dos grupos de empresas analisados. A seção 5 conclui.

\section{Referencial teórico}

\subsection{Requisitos necessários para a inovação}

O progresso tecnológico gerado pelas atividades inovativas é um elemento endógeno ao sistema capitalista (SCHUMPETER, 1911; AGHION; HOWITT, 1990). As inovações emergem em um ambiente no qual os agentes apresentam comportamentos diversos e a dinâmica tecnológica está em contínua mudança, em decorrência da competição entre as empresas por inovações que superem ou aprimorem as já existentes (SCHUMPETER, 1942).

$\mathrm{Na}$ atual sociedade do conhecimento (OECD, 2017) os novos produtos são cada vez mais sistêmicos e multifuncionais, acessando diversas áreas ou campos da ciência. O conhecimento se tornou insumo fundamental para as empresas, porém, diferentemente de ativos físicos, como máquinas, equipamentos e componentes, ele não é facilmente incorporado pelas empresas. A transferência de conhecimento requer aprendizado, capacidades prévias e esforço tecnológico (LALL, 1992; TEECE, 1998). Se, por um lado, o conhecimento codificado pode ser armazenado, transcrito e repassado por meio de manuais, por outro, o conhecimento tácito exige capacitação e esforço tecnológico para ser absorvido e replicado (TEECE, 1998). Dada essa especificidade, para obter retornos privados, as empresas precisam transformar seu conhecimento em inovações, o que irá influenciar diretamente a sua trajetória inovativa (TEECE, 1998).

Para inovar, cada vez mais as empresas precisam recorrer a novos métodos, que incluem aquisição de P\&D externa ou de empresas com ativos estratégicos para seu mercado de atuação, monitorar o mercado consumidor e a atividade de seus concorrentes e fazer parceiras com instituições externas no intuito de ampliar o escopo ou fundir o conhecimento existente. Este último ponto é importante, pois permite que empresas e parceiros acessem áreas do conhecimento que estão distantes do seu portfólio (COHEN; LEVINTHAL, 1990; CASSIMAN; VEUGELERS, 2002). A interação dos agentes está por trás do conceito de sistema de inovação (LUNDVALL, 1992). As empresas são os principais agentes produtores da inovação, mas a participação de outras instituições se torna crucial para definir o desempenho da trajetória traçada (TETHER, 2002). Dessa forma, o progresso tecnológico se beneficia da interação entre agentes que produzem e utilizam tecnologia gerada externamente (SCHUMPETER, 1942; AGHION; HOWITT, 1990).

Ao contrário do modelo linear de inovação, no modelo interativo (KLINE; ROSENBERG, 1986) argumenta-se que ativos e conhecimentos podem ser reconfigurados e recombinados para dar origem a produtos e tecnologias novas. Durante esse processo podem ocorrer diversos feedbacks oriundos de qualquer ponto da cadeia produtiva (COHEN; NELSON; WALSH, 2002) e, por isso, a inovação pode

\footnotetext{
${ }^{3}$ Agradeemos aos técnicos do IBGE responsáveis pela Pintec que se dispuseram discutir e preparar a tabulação.
} 
resultar tanto de esforços direcionados à $\mathrm{P} \& \mathrm{D}$ quanto de atividades rotineiras, internas ou externas à firma inovadora. Aprendizados práticos do tipo learning by doing, learning by interacting e learning by using incrementam a eficiência nas operações de produção e promovem a interação entre usuários e produtores (LUNDVALL, 1992; COHEN; NELSON; WALSH, 2002). Segundo Bell (1984) o processo de aprendizado interativo das firmas gera uma melhora nas técnicas produtivas decorrente da repetição diária de operações e da experiência acumulada ao resolver problemas. Há um tipo de aprendizado que demanda esforço intencional e direcionado, o qual Bell (1984) definiu como um sistema de feedbacks internos que envolvem avaliar, revisar, interpretar e aprimorar as experiências realizadas. Conforme apontado por Kline e Rosenberg (1986) os feedbacks referem-se às necessidades observadas do mercado e de potenciais usuários que indicam aprimoramentos na performance do produto a serem feitos na próxima rodada de produção.

O sucesso da inovação das firmas depende da integração de novos conhecimentos no processo inovativo, e parte desse conhecimento é proveniente de fontes externas (CASSIMAN; VEUGELERS, 2002). Num estudo sobre empresas inovadoras portuguesas (FARIA; LIMA; SANTOS, 2010) foi verificado que aquelas que consideraram a cooperação com estratégia de alta relevância possuem mais empregados, uma proporção maior deles têm ensino superior e dão mais importância à gestão dos spillovers de conhecimento. Essas empresas também tinham como característica comum fazer parte de um grupo e estar envolvida em atividades de P\&D. Outro estudo que analisou os países europeus (ABRAMOVSKY et al., 2009) comprovou que as firmas inovadoras que cooperaram possuem maior capacidade de apropriar-se de conhecimentos gerados externamente e apresentam níveis de desempenho globais mais altos. Além disso, também foi encontrado que firmas que cooperam tendem a lançar inovações que são novas para o mercado, e não apenas para a firma (TETHER, 2002), ou seja, a abrangência da inovação é maior.

No Brasil, uma análise com dados da Pintec entre 1998 e 2000 (CASSIOLATO; BRITTO; VARGAS, 2005) mostrou que a cooperação para inovar era pequena para a economia (apenas $11 \%$ do total de empresas inovadoras cooperaram). Porém, as relações firmadas foram bastante relevantes, especialmente para empresas que inovam e diferenciam produtos. Tessarin (2012) avaliou a cooperação de empresas com universidades e institutos de pesquisa através de um survey de inovação aplicado à 318 empresas brasileiras em meados de 2010 (BRSurvey) e encontrou que as universidades são mais procuradas pelas empresas por terem áreas de pesquisa mais abrangentes, em contraposição a especificidade da maior parte dos institutos. Bastos e Britto (2017) também utilizaram a Pintec para avaliar o período de 2003 a 2011. Eles identificaram que empresas nacionais registraram uma proporção menor de arranjos colaborativos com universidades, centros de pesquisa e de capacitação técnica quando comparadas com empresas estrangeiras, embora a taxa de participação das nacionais esteja crescendo mais rápido, notadamente entre empresas com até 500 empregados.

Diversos estudos sobre cooperação no Brasil se concentram na relação entre universidades/institutos de pesquisa e empresas (CASSIOLATO; BRITTO; VARGAS, 2005; BASTOS; BRITTO, 2017). Para analisar do ponto de vista das universidades, alguns autores se baseiam em informações do Diretório de Grupos de Pesquisa do Conselho Nacional de Desenvolvimento Científico e Tecnológico (CNPq). Por exemplo, Suzigan et al. (2009) conseguiram identificar que a pesquisa acadêmica é relevante para a criação e difusão de novos conhecimentos para as empresas. Já Rapini (2007) notou que os fluxos de conhecimentos e serviços oriundos dos grupos de pesquisa são utilizados pelas empresas principalmente em atividades rotineiras. Fernandes et al. (2010) observaram que ambos os parceiros obtêm benefícios com a cooperação: para as universidades, há ganhos intelectuais e econômicos; nos institutos de pesquisa, os benefícios são intelectuais; enquanto nas empresas há melhores resultados inovativos e produtivos.

No entanto, o sistema de inovação envolve diversos outros agentes que podem compartilhar competências e funções e que merecem uma análise detalhada.

\subsection{Influência das empresas multinacionais no desenvolvimento tecnológico}

Nas últimas décadas, as etapas produtivas foram estrategicamente realocadas em diversos países com a consolidação das estruturas de cadeias globais de valor. Em menor intensidade, a atividade 
inovativa está seguindo o mesmo trajeto. Há duas razões que levam as firmas a internacionalizarem suas atividades de pesquisa (DUNNING, 1994; OECD, 2016): a primeira é atender as condições locais do país hospedeiro por meio de customização de tecnologias e a segunda é buscar acesso a conhecimentos e tecnologias desenvolvidas no estrangeiro. Adaptar produtos e processos às preferências locais exige proximidade do mercado. Algumas tendências ou novas ideias podem ser absorvidas e implementadas em outros países ao redor do mundo, porém, a dinâmica inovativa depende da infraestrutura local de ciência e tecnologia e dos demais atores econômicos que formam as bases para disseminação de conhecimento (OECD, 2016; CASSIOLATO; LASTRES, 2017).

As empresas, especialmente as multinacionais, têm papel importante ao internacionalizar P\&D e inovação. São elas as responsáveis pela maior parte de P\&D realizada no planeta. No Japão e na Coreia do Sul, o volume de gastos em P\&D por empresas alcança $80 \%$ do total; nos EUA atinge cerca de $70 \%$ e nos países da OECD chega, em média, a 60\% (OECD, 2017). No geral, ao observar as maiores empresas inovadoras do mundo, nota-se a presença de grandes multinacionais com estoque de conhecimento acumulado ao longo de várias décadas.

Como consequência dessa internacionalização, o perfil da atividade inovativa nos países hospedeiros se altera. Alguns autores encontraram uma relação positiva entre a propriedade estrangeira e a atividade inovativa em países receptores. Por exemplo, Crescenzi, Gagliardi e Iammarino (2015) apontaram que essas empresas são a maior fonte de geração, transferência e difusão de tecnologias. Guadalupe, Kuzmina e Thomas (2012) mostraram que elas podem aumentar a taxa de inovação do país hospedeiro por meio da implantação de plantas industriais modernas e adoção de melhores práticas organizacionais. Segundo Falk (2008), a transferência de tecnologias desenvolvidas no país-sede para o país hospedeiro gera um efeito positivo nas atividades tecnológicas deste último porque exige o domínio de conhecimentos específicos, conduz a adaptação na linha de produção e atualização tecnológica, demanda recursos humanos qualificados e, por vezes, o desenvolvimento de parceiros de pesquisa. As empresas multinacionais também possuem vantagens em termos de tamanho e know-how tecnológico acumulado que lhes permitem diversificar melhor os riscos inerentes a atividade inovativa (DUNNING, 1994).

No entanto, Sánchez, Molero e Rama (2016) defendem que o país receptor pode desenvolver um perfil passivo e tornar-se dependente do progresso tecnológico externo. Quando a atividade inovativa desenvolvida no país hospedeiro é fraca, limita o seu potencial de desenvolvimento tecnológico e criativo (RAMA, 2008). A disponibilidade de tecnologia externa desenvolvida na matriz ou em outra filial pode desencorajar ou até substituir o investimento em pesquisa no país receptor e, consequentemente, não há internalização de novos conhecimentos (VEUGELERS, 1997). Segundo Lall (2000), as empresas multinacionais têm vantagens para criar novas tecnologias - que na verdade são novas para o mercado local, mas não para a empresa —, porque podem usar um mix de seus ativos (conhecimentos e tecnologias) e reproduzi-los em qualquer lugar. Mas o uso desses ativos estratégicos depende dos planos traçados pela matriz. Consoni $(2004$, p.97) ao analisar o setor automotivo no Brasil classificou as atividades de pesquisa feitas por filiais de multinacionais como "tropicalização", ou seja, voltadas para adaptação dos produtos finais às condições locais e totalmente dependentes de suas matrizes. Para Cassiolato e Lastres (2017), a multinacional que detém as principais capacitações e está organizada ao redor do mundo em posições únicas de barganha; ela tem condições de absorver as diferentes matrizes de conhecimentos disponíveis nos diferentes sistemas nacionais de inovação, e não os países hospedeiros. Se as multinacionais estrangeiras farão mais ou menos esforço tecnológico nos países em que elas se instalam, dependerá da infraestrutura científica local, do nível de qualificação da mão de obra, do marco regulatório e de políticas locais que exijam contrapartidas críveis (LALL, 1992, 2000).

Outro fator que impacta o desenvolvimento tecnológico do país receptor é o setor de atuação da empresa multinacional (SÁNCHEZ; MOLERO; RAMA, 2016), em razão de as oportunidades e intensidades tecnológicas serem distintas setorialmente (PAVITT, 1984; BRESCHI; MALERBA, 1997). Nos casos em que o avanço tecnológico é relativamente lento (como nos setores tradicionais), é provável que a fronteira tecnológica esteja menos distante do país receptor e a presença de empresas multinacionais não faça diferença significativa em termos da tecnologia desenvolvida localmente. No entanto, nos setores em que a tecnologia é atualizada rapidamente, é comum que os países em desenvolvimento 
estejam distantes da fronteira tecnológica. Nesse caso, a atuação das multinacionais estrangeiras em setores da vanguarda tecnológica pode influenciar o desenvolvimento tecnológico dos países hospedeiros.

Além disso, os investimentos em P\&D realizados no país-sede e nos países hospedeiros pelas empresas multinacionais podem ter magnitude diferente, sobretudo nos setores de maior intensidade tecnológica. Os dados dos EUA a respeito disso são bastante elucidativos. Esse país é o que mais investe em P\&D no planeta e suas multinacionais participam de várias etapas das cadeias globais de valor ao redor do mundo. A Tabela 1 exibe o percentual médio, entre 2009 a 2015, dos dispêndios em P\&D em relação às vendas efetuadas pelas empresas dos EUA, distinguindo-as a partir do local de atuação ${ }^{4}$.

Fica evidente que os investimentos em $\mathrm{P} \& \mathrm{D}$ feitos por empresas estadunidenses da indústria de transformação que atuam dentro do seu país são bem maiores do que daquelas que atuam fora dele, especialmente nos setores de alta tecnologia. Para a indústria de transformação, essa diferença é de três vezes e esse comportamento se replica para todos os demais setores manufatureiros e por categorias de intensidade tecnológica, como se observa na Tabela 1.

Tabela 1 - Investimentos em P\&D (em relação às vendas) de empresas estadunidenses, por local de atuação, média de 2009 a 2015 , em \%

\begin{tabular}{lccc}
\hline \multirow{2}{*}{$\begin{array}{l}\text { Setor de atividade e } \\
\text { categorias tecnológicas }\end{array}$} & \multicolumn{3}{c}{ Local de atuação } \\
\cline { 2 - 4 } & Dentro dos EUA & Fora dos EUA & Apenas no Brasil \\
\hline Alimentos & 0,52 & 0,26 & 0,11 \\
\hline Bebidas e fumo & 0,36 & 0,09 & - \\
\hline Têxteis, vestuário e produtos de couro & 0,74 & 0,54 & - \\
\hline Produtos de madeira & 0,76 & 0,20 & - \\
\hline Papel e celulose & 1,63 & 0,25 & - \\
\hline Impressão e atividades de apoio & 0,31 & 0,16 & - \\
\hline Coque e derivados & 0,32 & 0,00 & - \\
\hline Químicos exc. Farmacêuticos & 2,78 & 0,61 & 1,01 \\
\hline Produtos farmacêuticos & 15,06 & 3,60 & - \\
\hline Plástico e borracha & 1,30 & 0,81 & - \\
\hline Produtos minerais não-metálicos & 1,22 & 0,40 & 0,22 \\
\hline Metais básicos & 0,43 & 0,25 & 0,70 \\
\hline Produtos fabricados de metal & 1,34 & 0,54 & 1,06 \\
\hline Máquinas e equipamentos & 3,55 & 1,32 & 0,03 \\
\hline Informática e eletrônicos & 9,19 & 1,66 & 2,16 \\
\hline Máquinas e materiais elétricos & 3,60 & 1,24 & - \\
\hline Veículos a motor, partes e peças & 3,04 & 1,93 & 0,11 \\
\hline Outros equipamentos de transporte & 6,42 & 2,42 & 0,22 \\
\hline Móveis & 1,50 & 0,52 & 1,12 \\
\hline Baixa tecnologia & 0,67 & 0,23 & 1,06 \\
Média-baixa tecnologia & 0,47 & 0,27 & $\mathbf{0 , 9 0}$ \\
Média-alta tecnologia & 4,05 & 1,37 & \\
Alta tecnologia & 11,51 & 2,28 & $\mathbf{1 , 2 4}$ \\
\hline Indústria de transformação & $\mathbf{3 , 8 3}$ & & \\
\hline Pont: US. Bureau of Econom & & & \\
\hline
\end{tabular}

Fonte: U.S. Bureau of Economic Analysis. Cálculos e elaboração da autora.

Em geral, inicialmente as empresas multinacionais estabelecem seu centro de P\&D no país-sede e estrategicamente distribuem outros centros secundários de pesquisa motivados pelo acesso a ativos de interesse localizados no exterior (tanto ativos físicos como conhecimento e tecnologia) ou quando

\footnotetext{
${ }^{4}$ De acordo com o U.S. Bureau of Economic Analysis são consideradas empresas estadunidenses quando o capital majoritário pertence a residentes dos EUA. O local de atuação consiste na unidade territorial em que a filial da empresa está realizando suas operações, que pode ser doméstico ou estrangeiro.
} 
encontram algum tipo de vantagem tecnológica, gerencial ou organizacional sobre seus concorrentes em outros países (DUNNING, 1994).

As diferenças setoriais exibidas na Tabela 1 são explicadas principalmente pelas oportunidades tecnológicas de cada setor, que tendem a ser maiores nos setores da vanguarda tecnológica devido a maiores possiblidades de aplicação da tecnologia em novos produtos (BRESCHI; MALERBA, 1997).

Quanto ao Brasil, as filiais estadunidenses investem menos ainda em P\&D (em percentual das vendas) que nos demais países hospedeiros, em todas as categorias de intensidade tecnológica da manufatura (Tabela 1). Mesmo nos setores automobilístico e de outros equipamentos de transportes, nos quais há grande presença de filiais estadunidenses atuando no Brasil há várias décadas, o percentual das vendas investido em P\&D no Brasil no agregado do setor é similar ao investido em outros países hospedeiros e muito inferior ao investido nos $\mathrm{EUA}^{5}$. A única exceção está no setor de químicos, exceto farmacêutico (Tabela 1), em que o Brasil recebe 1,01\% dos dispêndios em P\&D em relação às vendas das empresas estadunidenses aqui instaladas, frente a $0,61 \%$ do que é feito no mundo, exceto nos EUA (mas ainda assim abaixo dos 2,78\% feitos nos EUA).

\section{Procedimentos metodológicos}

\subsection{Dados}

As informações desta pesquisa são inéditas e provêm da Pesquisa de Inovação Tecnológica (Pintec), do IBGE, que segue as definições e recomendações sobre atividades inovativas do Manual de Oslo e é adotado nos surveys de inovação dos países da OECD (OECD, 2017).

Foi utilizada a Pintec de 2003 que engloba as empresas que inovaram durante o período de 2001 a 2003 (IBGE, 2005) e de 2014, para o triênio 2012-2014 (IBGE, 2016) ${ }^{6}$. Com isso, busca-se captar modificações de caráter estrutural e que sejam menos influenciadas pelo ciclo de negócios. Ressalta-se que a última Pintec, ao captar o período de 2012-2014, praticamente não foi contaminada pela crise político-econômica que se agravou em 2015 e 2016. Todos os dados monetários apresentados foram deflacionados para valores de 2016 pelo deflator implícito do PIB calculado a partir das contas nacionais trimestrais do IBGE.

No triênio 2001-2003 foram pesquisadas aproximadamente 28 mil empresas e no triênio 20122014 foram 42 mil empresas, sendo $80 \%$ desse total correspondente à indústria de transformação. Nesse período, o grupo de empresas inovadoras representou $70 \%$ da receita líquida de vendas de toda a indústria de transformação brasileira.

\subsection{Estratégia de seleção}

Especificamente, esta pesquisa demandou uma tabulação especial de todas as empresas da indústria de transformação que compõem o estrato certo amostral, segmentadas em quatro grupos: empresas estrangeiras que inovaram com relações de cooperação; empresas estrangeiras que inovaram sem relação de cooperação; empresas nacionais que inovaram com relações de cooperação; e empresas nacionais que inovaram sem relação de cooperação ${ }^{7}$. Essa forma de analisar as informações permitiram uma abordagem distinta, não observada nos trabalhos prévios.

A cooperação para inovação é definida como "a participação ativa da empresa em projetos conjuntos de $\mathrm{P} \& \mathrm{D}$ e outros projetos de inovação com outra organização (empresa ou instituição), o que não implica, necessariamente, que as partes envolvidas obtenham benefícios comerciais imediatos" (IBGE, 2014, p. 97). Contratar produtos e serviços de outra organização sem participar ativamente do

\footnotetext{
${ }^{5}$ No agregado do setor de equipamentos de transportes (inclui veículos e outros equipamentos de transportes), as filiais estadunidenses investiram no Brasil 2,16\% das vendas em P\&D; nos demais países hospedeiros 1,96\% e nos Estados Unidos $4,68 \%$.

${ }^{6}$ A primeira edição da Pintec ocorreu em 2000. Porém, optou-se por utilizar dados com início em 2003 pelo fato de as empresas estarem mais familiarizadas com o entendimento e a aplicação do conceito de inovação.

${ }^{7}$ Optou-se por não selecionar empresas de capital misto porque o seu dispêndio total com inovação foi pequeno. Em 2003 as empresas de capital misto eram 250 (0,9\% do total de empresas inovadoras), e em 2014 eram 440 (1,1\%) e realizaram 1,1\% do dispêndio total com inovação em ambos os períodos.
} 
desenvolvimento não é considerado cooperação, mas apenas uma atividade comercial. A investigação sobre a cooperação englobará todos esses parceiros utilizados para inovar no Brasil.

Por fim, dado que os setores produtivos contribuem de formas diferentes para o desenvolvimento tecnológico do país devido as oportunidades tecnológicas de cada um, também foi solicitada a desagregação da indústria de transformação nas quatro categorias de intensidade tecnológica $\mathrm{OECD}$ : baixa, média-baixa, média-alta e alta tecnologia.

A combinação das informações resultou em dados inéditos, que não estão disponíveis publicamente, e por isso garantem uma abordagem diferenciada sobre o perfil da inovação.

\section{Resultados}

No Brasil, a taxa de inovação evoluiu pouco ao longo de uma década. Em 2003, de cada 100 empresas, apenas 33 inovaram e, em 2014, 36 de cada 100 inovaram $^{8}$, de acordo com os dados da Pintec. No comparativo internacional, a taxa de inovação brasileira é ligeiramente inferior à dos 15 países que formaram inicialmente a União Europeia (KOELLER, 2018). Contudo, apesar de as empresas inovadoras representarem um terço do número de firmas, elas detêm mais de dois terços da receita líquida de vendas. Logo, as empresas inovadoras possuem maior market share em comparação com as não inovadoras. No entanto, existe um grupo específico de empresas com maior esforço inovador e que detém elevada parcela do mercado: aquelas que realizaram cooperação para inovar.

\subsection{Perfil da cooperação para inovar na indústria de transformação}

Quando as empresas enfrentam dificuldades em reunir competências necessárias para implementar inovações, elas podem unir esforços com outros agentes. A cooperação tem importância fundamental para a inovação, pois amplia o acesso das empresas a uma infinidade de recursos desenvolvidos externamente (LEVIN et al., 1987; ZUNIGA et al., 2016). Nesse contexto, fontes internas e externas de insumos para a inovação são vistas como formas complementares, e não substitutos à inovação feita no laboratório de P\&D (CASSIMAN; VEUGELERS, 2002; FARIA; LIMA; SANTOS, 2010).

Do total das empresas da indústria de transformação brasileira, as não inovadoras representaram cerca de dois terços do total em 2003 e 2014. O restante atribuído às empresas inovadoras pode ser dividido entre as que cooperaram e as que não cooperaram (Gráfico 1). Embora ainda seja muito baixo o percentual de empresas que inovam com algum tipo de parceria, as cooperações têm crescido na indústria de transformação. Em 2003, apenas 1,5\% das empresas inovadoras cooperaram e, em 2014, foram $5,6 \%$ do total.

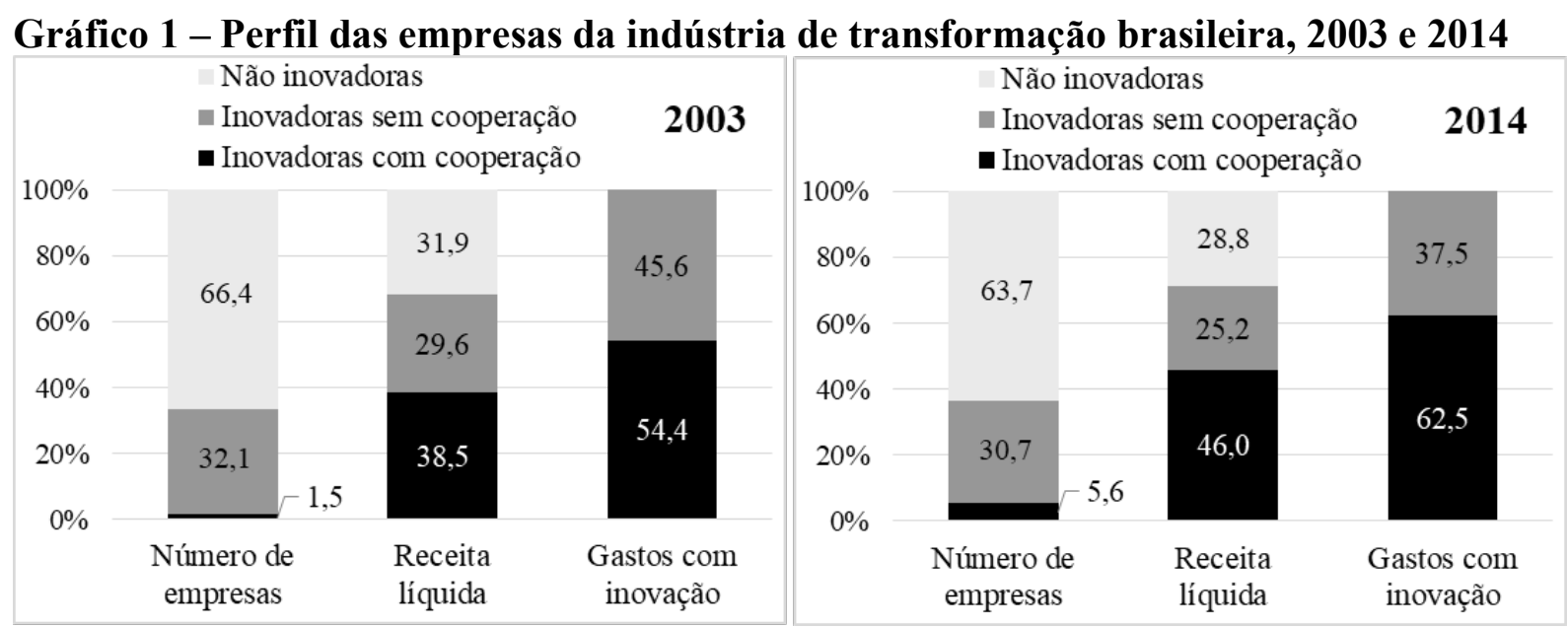

Nota: Não foram consideradas empresas de capital misto.

Fonte: Extração especial da PINTEC/IBGE. Cálculos e elaboração da autora.

De fato, as empresas que inovaram com cooperação representam uma ilha de excelência no universo das empresas brasileiras, pois elas possuem indicadores que se destacam em relação às empresas

${ }^{8}$ Acentua-se que o período de referência é trienal. Abrange 2001-2003 na Pintec 2003 e 2012-2014 na Pintec 2014. 
que inovaram sem realizar algum tipo de parceria, como será visto na sequência. Assim como foi apontado pela literatura (COHEN; LEVINTHAL, 1990; TEECE, 1998), pode-se esperar que firmas com alto nível de capacitação estivessem melhor preparadas para desenvolver projetos com parceiros. Há uma variedade de fatores que levam as firmas a estabelecer arranjos cooperativos para inovar, mas em geral relaciona-se com o fato da firma não ter todas as capacidades ou recursos necessários e por desejarem dividir os riscos associados à inovação (TETHER, 2002).

No Brasil, a origem do capital controlador tem sido destacada nos estudos de inovação tecnológica devido à elevada presença de filiais de multinacionais estrangeiras no país (QUEIROZ; CARVALHO, 2005; CASSIOLATO; MATOS; LASTRES, 2014; BASTOS; BRITTO, 2017). Praticamente todo o aumento no número de empresas que cooperaram para inovar entre 2003 e 2014 correspondeu àquelas de controle do capital nacional (Gráfico 2). Apesar da pequena proporção, essas empresas concentraram mais da metade da receita líquida de vendas e dos dispêndios com atividades inovativas, inclusive por origem do capital (Gráfico 2), tratando-se dessa forma, de um grupo especial a ser estudado.

Em 2014, as empresas nacionais representaram a maioria das empresas. No entanto, em termos de receita líquida de venda ou gastos com atividades inovativas, as de controle estrangeiro que cooperaram para inovar somaram cerca de um quarto do total e as de controle nacional que cooperaram representaram pouco mais de um terço (Gráfico 2). Além disso, as empresas estrangeiras que cooperaram para inovar tinham maior porte em relação aos demais grupos de empresas em relação aos demais grupos de empresas (Tabela 2).

\section{Gráfico 2 - Perfil das empresas inovadoras da indústria de transformação brasileira, por origem do capital e por relação de cooperação para inovar, 2003 e 2014}

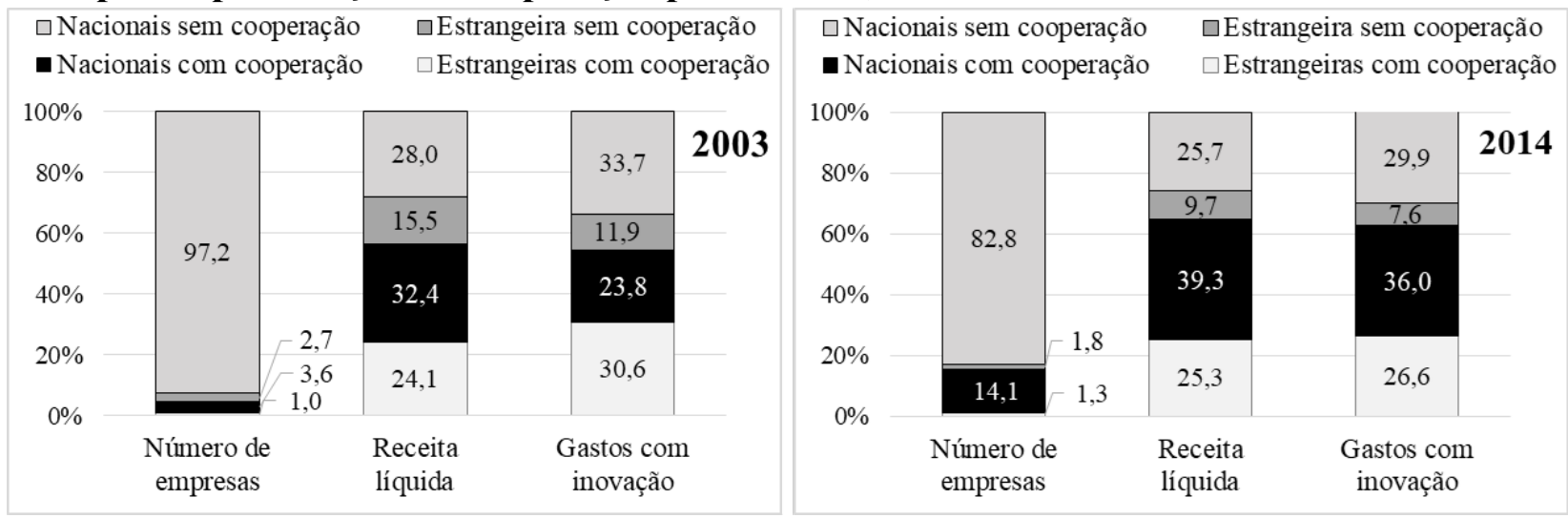

Nota: Não foram consideradas empresas de capital misto.

Fonte: Extração especial da PINTEC/IBGE. Cálculos e elaboração da autora.

Em síntese, os dispêndios com inovação foram feitos, majoritariamente, por empresas que cooperaram para inovar, de capital controlador nacional e estrangeiro (Gráfico 2). É interessante notar que a estratégia de cooperar para inovar vem sendo crescentemente adotada pelas empresas nacionais. Além do aumento no número de empresas nacionais que inovaram realizando cooperação, a parcela dos gastos destinada por elas à inovação cresceu 12 pontos percentuais entre 2003 e 2014 (Gráfico 2). Em sentido contrário, no mesmo período, as estrangeiras que cooperaram reduziram um pouco sua participação em quatro pontos percentuais.

Os gastos com atividades inovativas sinalizam esforços no sentido de melhorar o acervo tecnológico e promover o desenvolvimento e/ou a implantação de novos produtos ou processos na rotina da empresa. Além do investimento em P\&D, tais ações incluem a aquisição de P\&D externa, de conhecimentos externos, de máquinas e equipamentos, treinamento, introdução da inovação no mercado e desenvolvimento do projeto industrial ${ }^{9}$. A intensidade em atividades inovativas é dada pela razão dos gastos totais a elas relacionados e a receita líquida de vendas (ver a penúltima coluna da Tabela 2).

\footnotetext{
${ }^{9}$ A aquisição de softwares foi incluída como atividade inovativa em 2014, porém, para manter a mesma base de comparação em relação a 2003, não serão computados esses gastos.
} 
A intensidade em $P \& D$ (gastos em $\mathrm{P} \& \mathrm{D}$ como proporção da receita líquida de vendas) das empresas nacionais que cooperaram praticamente não variou entre 2003 e 2014, mantendo-se próxima de 1,0\% (Tabela 2). Merecem destaque dentro desse grupo aquelas incluídas na categoria de alta tecnologia que investiram 5,6\% da receita líquida em P\&D em 2014, embora possuam um peso pequeno na estrutura produtiva brasileira.

Entre as empresas nacionais, a diferença em relação às que não cooperaram é significativa, considerando que essas gastaram apenas $0,4 \%$ da sua receita líquida em P\&D no mesmo período. Entre as empresas estrangeiras, as que cooperaram tiveram praticamente a mesma intensidade que as nacionais que cooperaram (1,1\% em 2014). Além disso, todas as categorias de intensidade tecnológica das empresas estrangeiras que não cooperaram apontaram intensidades em P\&D próximas aos grupos das empresas nacionais que também não cooperaram (Tabela 2).

Tabela 2 - Indicadores das empresas inovadoras da indústria de transformação brasileira, 2003 e 2014

\begin{tabular}{|c|c|c|c|c|c|c|c|c|c|}
\hline \multirow[t]{2}{*}{$\begin{array}{l}\text { Grupo de } \\
\text { empresa }\end{array}$} & \multirow[t]{2}{*}{$\begin{array}{l}\text { Intensidade } \\
\text { tecnológica }\end{array}$} & \multicolumn{2}{|c|}{$\begin{array}{l}\text { Receita líquida } \\
\text { (R\$ bilhões de } \\
\text { 2016) }\end{array}$} & \multicolumn{2}{|c|}{$\begin{array}{c}\text { P\&D / } \\
\text { Receita } \\
\text { líquida (\%) }\end{array}$} & \multicolumn{2}{|c|}{$\begin{array}{c}\text { Atividades } \\
\text { inovativas } / \text { Receita } \\
\text { líquida }(\%)\end{array}$} & \multicolumn{2}{|c|}{$\begin{array}{l}\text { Porte } \\
\text { médio }\end{array}$} \\
\hline & & 2003 & 2014 & 2003 & 2014 & 2003 & 2014 & 2003 & 2014 \\
\hline \multirow{5}{*}{$\begin{array}{l}\text { Estrangeiras } \\
\text { com } \\
\text { cooperação }\end{array}$} & Baixa & 72,9 & 97,1 & 0,4 & 0,2 & 4,2 & 2,8 & 18,4 & 14,6 \\
\hline & Média-baixa & 50,9 & 89,5 & 0,5 & 0,7 & 3,2 & 2,0 & 19,7 & 11,6 \\
\hline & Média-alta & 234,7 & 297,6 & 1,6 & 1,4 & 4,4 & 3,0 & 23,8 & 13,6 \\
\hline & Alta & 58,5 & 70,8 & 1,2 & 1,3 & 4,8 & 2,8 & 16,3 & 12,6 \\
\hline & SubTotal & 417,1 & 555,0 & 1,2 & 1,1 & 4,3 & 2,8 & 20,8 & 13,2 \\
\hline \multirow{5}{*}{$\begin{array}{l}\text { Estrangeiras } \\
\text { sem } \\
\text { cooperação }\end{array}$} & Baixa & 70,9 & 47,6 & 0,1 & 0,3 & 1,6 & 0,9 & 8,1 & 7,5 \\
\hline & Média-baixa & 32,8 & 21,2 & 0,4 & 0,6 & 3,5 & 4,6 & 2,8 & 2,1 \\
\hline & Média-alta & 134,0 & 113,2 & 0,5 & 0,9 & 2,5 & 2,1 & 4,6 & 3,0 \\
\hline & Alta & 30,3 & 31,5 & 0,4 & 1,0 & 4,1 & 1,8 & 5,6 & 7,9 \\
\hline & SubTotal & 268,7 & 213,5 & 0,4 & 0,7 & 2,6 & 2,0 & 4,9 & 3,6 \\
\hline \multirow{5}{*}{$\begin{array}{l}\text { Nacionais com } \\
\text { cooperação }\end{array}$} & Baixa & 125,0 & 249,1 & 0,2 & 0,5 & 2,0 & 2,5 & 4,6 & 1,3 \\
\hline & Média-baixa & 312,2 & 414,5 & 0,6 & 0,8 & 1,5 & 1,8 & 15,1 & 3,5 \\
\hline & Média-alta & 111,8 & 170,5 & 2,1 & 1,4 & 5,1 & 2,8 & 7,2 & 1,5 \\
\hline & Alta & 12,2 & 30,4 & 3,7 & 5,6 & 8,0 & 8,2 & 1,4 & 0,8 \\
\hline & SubTotal & 561,3 & 864,5 & 0,9 & 1,0 & 2,5 & 2,4 & 7,8 & 1,8 \\
\hline \multirow{5}{*}{$\begin{array}{l}\text { Nacionais sem } \\
\text { cooperação }\end{array}$} & Baixa & 256,9 & 280,6 & 0,2 & 0,2 & 3,8 & 2,6 & 0,3 & 0,2 \\
\hline & Média-baixa & 111,6 & 141,0 & 0,3 & 0,4 & 4,0 & 4,0 & 0,3 & 0,2 \\
\hline & Média-alta & 94,3 & 125,8 & 0,9 & 0,8 & 4,4 & 2,9 & 0,3 & 0,3 \\
\hline & Alta & 23,1 & 17,1 & 1,6 & 1,5 & 5,3 & 4,6 & 0,3 & 0,2 \\
\hline & SubTotal & 486,0 & 564,4 & 0,4 & 0,4 & 4,0 & 3,1 & 0,3 & 0,2 \\
\hline \multicolumn{2}{|c|}{ Empresas estrangeiras } & 685,8 & 768,5 & 0,9 & 1,0 & 3,6 & 2,6 & 9,1 & 7,6 \\
\hline \multirow{2}{*}{\multicolumn{2}{|c|}{$\begin{array}{l}\text { Empresas nacionais } \\
\text { Ind. de transformação }\end{array}$}} & $1.047,2$ & $1.428,9$ & 0,7 & 0,8 & 3,2 & 2,7 & 0,5 & 0,4 \\
\hline & & $1.733,0$ & $2.197,4$ & 0,7 & 0,9 & 3,3 & 2,6 & 0,9 & 0,7 \\
\hline
\end{tabular}

Nota: Porte médio = (receita líquida / número de empresas). Receita líquida a preços de 2016, calculado pelo deflator do PIB, a partir das Contas Nacionais Trimestrais.

Fonte: Tabulação especial da PINTEC/IBGE. Cálculos e elaboração da autora.

Já a intensidade dos gastos com atividades inovativas mostrou redução em todos os grupos de empresas de 2003 a 2014. Entre as estrangeiras, as que realizaram cooperação mantiveram intensidade superior frente às que não cooperaram, porém, entre as nacionais, ocorreu o oposto (Tabela 2). Isso pode indicar que as empresas nacionais que não cooperaram - que estão em maior número e apresentam menor receita líquida - investiram mais em atividades inovativas desenvolvidas por agentes externos e não nos seus próprios laboratórios de P\&D. Esse tipo de atividade, como aquisição de máquinas e equipamentos direcionados à inovação, apesar de exigir habilidades para realizar a adaptação interna, é considerado de menor esforço em termos de desenvolvimento tecnológico relativo à $\mathrm{P} \& \mathrm{D}$. 
O porte médio também pode influenciar a taxa de inovação ao interferir na capacidade da empresa em mobilizar recursos, acessar redes de pesquisa e internalizar novas tecnologias. Segundo estudo de Kannebley Junior, Porto e Pazello (2004), para as empresas inovadoras brasileiras, o tamanho contribui positivamente para a probabilidade de a empresa inovar. Na Tabela 2, nota-se que as empresas nacionais que não cooperaram eram as menores entre os grupos analisados. As que cooperaram tinham porte médio um pouco maior, mas, como em 2014 houve aumento expressivo no número de empresas desse grupo, sem incremento da receita na mesma dimensão, verifica-se que o porte médio desse grupo em 2014 caiu em relação a 2003. Já o grupo das estrangeiras que cooperaram destoou pelo seu maior porte médio: em 2014 elas foram sete vezes maiores que as empresas nacionais que cooperaram.

Os dados das categorias tecnológicas comprovam que setores de maior intensidade tecnológica precisam atualizar-se mais rapidamente e inovar mais, conforme os apontamentos feitos por Pavitt (1984). As categorias de alta e média-alta tecnologia investiram mais em P\&D do que as demais. No Brasil, a receita das empresas inovadoras estrangeiras da indústria de transformação esteve concentrada na categoria de média-alta intensidade tecnológica. As empresas de controle estrangeiro dessa categoria que cooperaram gastaram em $\mathrm{P} \& \mathrm{D}$, em 2014, o mesmo montante que as filiais de empresas estadunidenses despenderam fora dos EUA, embora tenha sido apenas um quarto do que foi gasto dentro dos EUA pela mesma categoria (Tabelas 1 e 2). Já em relação às empresas nacionais, a receita se concentrou em baixa e média-baixa tecnologia, de acordo com o padrão de especialização da manufatura nacional, que concentra cerca de dois terços da produção nessas categorias tecnológicas (MORCEIRO, 2018). Por sua vez, as empresas nacionais que cooperam de média-baixa tecnologia investiram em P\&D três vezes mais do que as multinacionais estadunidenses investiram no seu país e também três vezes mais do que elas aplicaram fora dele (Tabelas 1 e 2). As empresas que não cooperaram nacionais e estrangeiras gastaram com $\mathrm{P} \& \mathrm{D}$ volumes menores em suas respectivas categorias tecnológicas em comparação às empresas dentro e fora dos EUA.

Quanto à categoria de baixa tecnologia, o maior gasto foi destinado às demais atividades inovativas. Pavitt (1984) descreve esses setores como dominados por fornecedores, pois dependem de tecnologias e inovações feitas em outros setores. Nesta categoria, as empresas nacionais que cooperaram gastaram cinco vezes o montante gasto com $\mathrm{P} \& \mathrm{D}$, enquanto as nacionais que não cooperaram gastaram 13 vezes mais. As empresas estrangeiras que cooperaram foram as que mais despenderam recursos em atividades inovativas proporcionalmente à sua receita líquida de vendas: elas aplicaram 14 vezes mais do que o destinado à $\mathrm{P} \& \mathrm{D}$ e as estrangeiras que não cooperaram gastaram três vezes mais. Isso ocorre porque, embora as empresas de baixa tecnologia sejam assim classificadas em razão do menor investimento em $\mathrm{P} \& \mathrm{D}$, elas executam outros tipos de atividades inovativas, principalmente a aquisição de máquinas e equipamentos (conforme será mostrado adiante). A categoria de baixa tecnologia demanda componentes tecnológicos, máquinas e equipamentos das categorias de média-alta e alta tecnologia, sendo indiretamente responsáveis pelo desenvolvimento tecnológico dos fornecedores desses produtos. Assim, P\&D não é um fator delimitador da atividade inovativa das empresas de menor intensidade tecnológica, pois essas categorias absorvem inovações incorporadas nos produtos tecnológicos que elas compram.

O tipo de atividade inovativa realizada impacta também nos resultados da inovação. Em 2014, em geral, a inovação gerou manutenção da participação da empresa no mercado e melhoria na qualidade dos produtos, enquanto para as que mais fizeram $P \& D$ - que são as que cooperaram -, a inovação gerou principalmente melhoria na qualidade do produto (TESSARIN, 2018).

\subsection{Parceiros das empresas na cooperação para inovar}

$\mathrm{Na}$ Pintec, as empresas indicam quais parcerias utilizaram para inovar e qual sua importância (alta, média, baixa importância ou irrelevante). Para captar as parcerias mais importantes, foram consideradas apenas as de alta importância. O eixo vertical do Gráfico 3 indica a proporção de empresas em cada categoria tecnológica que utilizou o parceiro citado, sendo que uma mesma empresa pode fazer parcerias com mais de um ator do sistema.

A cooperação foi realizada preponderantemente com dois parceiros: clientes e fornecedores, que estão em contato frequente para estabelecer parcerias estratégicas, acompanhar o processo produtivo e verificar possíveis adaptações sobre propriedades e requisitos técnicos do produto adquirido (COHEN; 
LEVINTHAL, 1990). Como a funcionalidade do produto depende dos seus componentes, peças e subsistemas interligados, desse trabalho conjunto surgem soluções de problemas e/ou demandas que modificam os insumos e conferem novas características ao bem final. A relação entre usuários e produtores de bens de capital também é crucial em alguns processos inovativos que precisam desenvolver ou adaptar máquinas e equipamentos para a produção de um produto novo (LUNDVALL, 1992). Neste ponto, os feedbacks apontados por Bell (1984) e Kline e Rosenberg (1986) entre uma área da empresa e clientes ou fornecedores são os principais insumos da parceria. Por exemplo, no setor de produtos plásticos é comum que empresas contatem seus fornecedores de resinas petroquímicas para discutirem projetos de adaptação no insumo a fim de alterar o produto final. As demandas incluem a necessidade de produzir peças mais rígidas e resistentes a choques, no caso de peças automotivas, ou nova formulação que permita moldar o produto a temperaturas mais elevadas sem perder as características.

Segundo Erber (2010), as empresas brasileiras que inovaram mais em produtos estabeleceram mais parcerias com clientes e consumidores, enquanto as empresas que focaram as inovações em processos utilizaram os fornecedores mais assiduamente. As empresas cooperam com seus consumidores ao divulgar ou oferecer produtos em fase de teste ou pré-lançamento, buscando aumentar as chances dos clientes aprovarem a inovação. Consequentemente, conhecem as preferências dos seus consumidores, aumentam a confiança dos usuários em seus produtos e reduzem os riscos associados ao lançamento da inovação no mercado (KLINE; ROSENBERG, 1986; TETHER, 2002). Por sua vez, a cooperação com fornecedores compartilha muitas das razões da relação com consumidores. Mas no caso dos fornecedores, envolve também decisões estratégicas para obter maior eficiência na produção e a uma maior focalização em competências centrais, que por sua vez criam demanda para parcerias em atividades complementares (TETHER, 2002; FARIA; LIMA; SANTOS, 2010).

\section{Gráfico 3 - Parceiros utilizados na cooperação para inovar na manufatura brasileira, em \% do total dos grupos de empresas, 2003 e 2014}

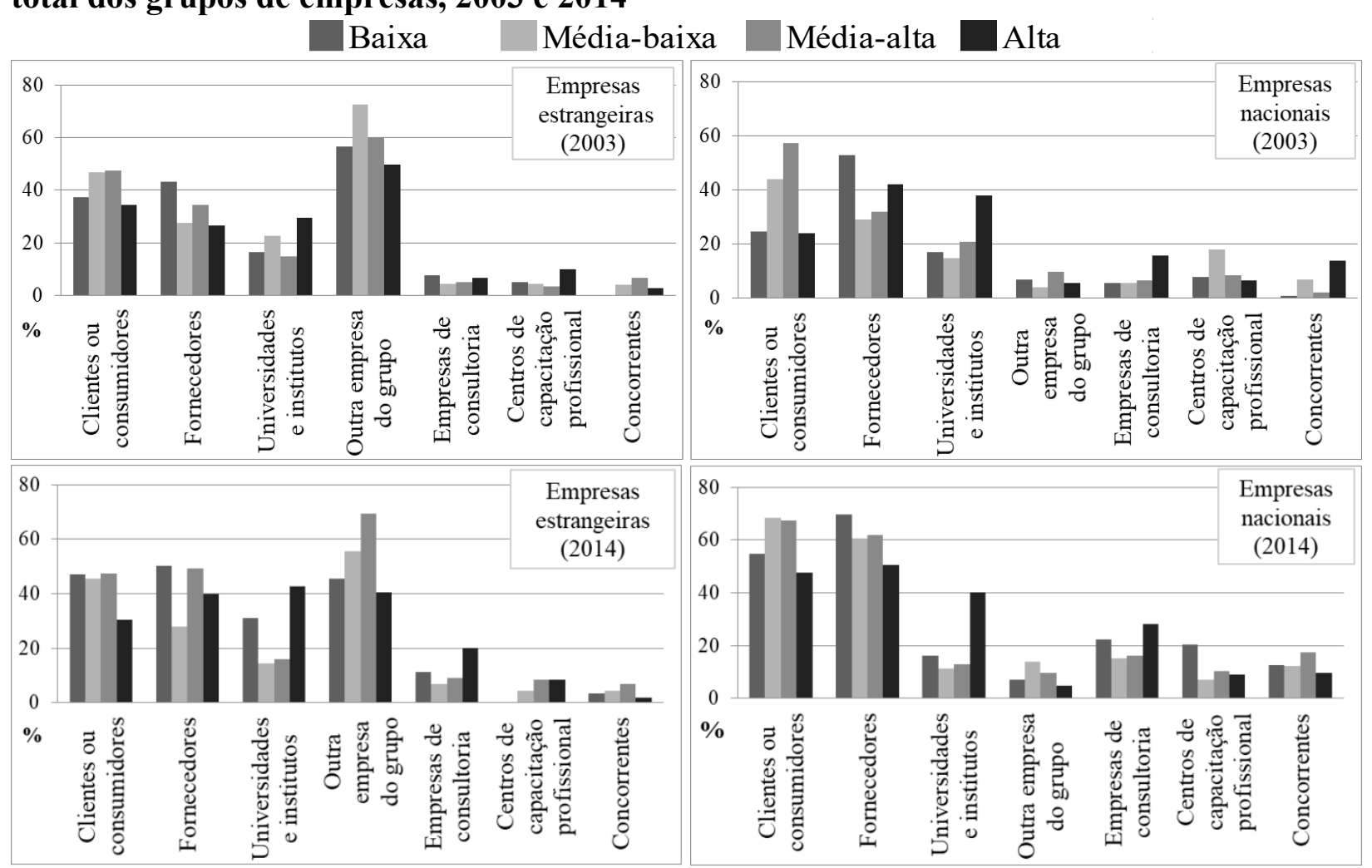

Nota: uma empresa pode cooperar com mais de uma opção.

Fonte: Tabulação especial da PINTEC - IBGE. Elaboração da autora.

A interação com universidades e institutos de pesquisas não foi fortemente utilizada por empresas nacionais, exceto no caso de alta tecnologia (Gráfico 3). A capacidade de absorção das empresas é particularmente importante para diferenciar os tipos de acordos de cooperação realizados, pois permitirá 
com que elas se apropriem do conhecimentos externos e internalizem de modo mais rápido as mudanças tecnológicas (CASSIMAN; VEUGELERS, 2002). Por isso, nem todos os setores produtivos ou empresas estão aptos a estabelecerem parcerias de maior complexidade. A interação com a universidade ocorre quando é requerido conhecimentos específicos, os quais, por sua vez, também demandam outros conhecimentos científicos acumulados que ajudam principalmente a confrontar problemas técnicos que demandam pesquisa (KLINE; ROSENBERG, 1986).

No entanto, no Brasil, as universidades e institutos de pesquisa, assim como outras estruturas científicas, foram instaladas tardiamente em comparação aos países desenvolvidos (SUZIGAN; ALBUQUERQUE, 2011). A principal universidade do país, a Universidade de São Paulo (USP), tem menos de 100 anos de existência, enquanto várias universidades europeias atuam há mais de quatro séculos. Há diversas formas de a universidade auxiliar no desenvolvimento tecnológico das empresas, como, por exemplo, por meio de novos instrumentos, técnicas e avanço no conhecimento científico (FERNANDES et al., 2010). Entre as principais razões que levaram empresas a cooperarem com universidades e institutos de pesquisa estão contratar pesquisa que não realizava (para empresas de alta e média-alta tecnologia) e para utilizar recursos disponíveis na universidade ou instituto (as de baixa e média-baixa) (TESSARIN, 2012).

Para as empresas estrangeiras, as parcerias feitas com fornecedores e clientes estão em segundo e terceiro lugar entre as mais relevantes, principalmente para a categoria de média-alta tecnologia. A principal forma de cooperação se dá com outra empresa do grupo, com maior relevância nas categorias de média-alta e média-baixa. Além disso, Tessarin (2018) observou que a localização da outra empresa do grupo é predominantemente no exterior. Uma multinacional tem a vantagem de ter acesso a novos conhecimentos por meio da sua rede de subsidiárias (JIMÉNEZ-JIMÉNEZ; MARTÍNEZ-COSTA; SANZ-VALLE, 2014). Grandes grupos empresariais têm elevado estoque de recursos internos e podem cooperar mais efetivamente (GUADALUPE; KUZMINA; THOMAS, 2012) e as próprias subsidiárias podem gerar novos conhecimentos, assim como podem absorver tecnologias desenvolvidas pela matriz. No entanto, em termos de transbordamentos tecnológicos locais, o potencial desse tipo de cooperação pode ser limitado, caso a estratégia da empresa seja apenas adaptar o projeto feito por outra firma do grupo sem desenvolver capacitações locais. Nesse caso, a inovação ocorre apenas para copiar ou tropicalizar a tecnologia, ou seja, para dar um retoque ao projeto desenvolvido fora e adequá-lo ao contexto do país hospedeiro ${ }^{10}$ (CONSONI, 2004). Como consequência, a inovação feita no país seguiria uma estratégia de adaptação das inovações desenvolvidas em outras unidades da empresa pelo mundo. Apesar do esforço tecnológico para adaptação desses produtos às características do mercado consumidor nacional, a essência da tecnologia foi desenvolvida no exterior.

Esse tipo de cooperação com outra empresa do grupo se fez muito pouco presente entre as empresas nacionais de qualquer categoria tecnológica no período. Tal fato se deve ao papel pouco ativo na interação ou a pouca existência de grandes grupos empresariais de capital nacional. Kannebley Junior, Porto e Pazello (2004) já haviam estimado que, na economia brasileira, a grande maioria das empresas inovadoras é independente, ou seja, não faz parte de um grupo de empresas.

Outras instituições, como empresas de consultoria, centros de capacitação profissional e concorrentes, são menos utilizados pelas empresas, sejam elas nacionais ou estrangeiras. No caso dos concorrentes, por um lado, pode ser uma opção das empresas não dividir informações com seus competidores diretos, mas, por outro, mostra que é muito raro uma estratégia de compartilhamento de custos e riscos associados ao desenvolvimento de um projeto estagnado que seria de interesse para ambos (KANNEBLEY JUNIOR; PORTO; PAZELLO, 2004). Concorrentes poderiam cooperar quando enfrentam problemas comuns, especialmente de cunho técnico ou regulatório. Também há evidências de novas empresas concorrentes entre si que decidem colaborar para fazer frente a um terceiro concorrente maior e estabelecido a mais tempo no mercado (TETHER, 2002). Quanto aos centros de capacitação

\footnotetext{
${ }^{10}$ Alguns exemplos conhecidos são: a adaptação da resistência de pneus automotivos para que sejam eficientes e suportem a elevada temperatura do asfalto no Brasil; a adaptação de produtos elétricos para a voltagem das residências brasileiras, que ainda pode diferir entre as regiões do país; a adaptação de produtos de higiene pessoal às características da população, principalmente em produtos para a pele e proteção solar.
} 
profissional, são empresas de capital nacional e de menor porte (menos de 500 empregados) que utilizam mais esse tipo de cooperação (BASTOS; BRITTO, 2017).

Em geral, nota-se que a cooperação para inovar se manifesta principalmente nos aprendizados do tipo learning-by-doing (ARROW, 1962). Essa interação é mais corriqueira porque faz parte da rotina operacional das empresas e se aproveita de feedbacks existentes na cadeia de produção, os quais fornecem ideias e insumos para melhoramentos e adaptações que resultam em inovações no produto final (BELL, 1984; KLINE; ROSENBERG, 1986).

A partir do tipo de parceria estabelecida, nota-se que a estratégia inovativa da maioria das empresas não prevê cooperações de longo prazo (como tradicionalmente são as relações com universidades e institutos de pesquisa) e não está focada em gerar inovações radicais ou em desenvolver novidades de âmbito mundial, concentrando-se mais na solução de problemas do dia a dia.

\subsection{Fontes das informações que dão origem a inovação}

No processo de inovação tecnológica, as empresas podem consultar diversas fontes de informação para obter inspiração e orientação para os projetos (IBGE, 2004). As 14 fontes de informação consultadas são mostradas no Gráfico 4. Elas representam a capacidade das empresas em absorver novos conhecimentos, combinar informações e ainda auxiliam a compreender como surgem as inovações.

A maior parte das ideias implementadas pelas empresas inovadoras provém de fontes externas, sobretudo fornecedores e clientes (pontos 4 e 5 do Gráfico 4). Em 2014 houve concentração ainda maior nessas duas fontes de informação no total das empresas inovadoras da indústria de transformação. Lundvall (1992) indicou que essas duas fontes são o modo mais comum de estimular o aprendizado pela prática. Para as empresas nacionais, os concorrentes e as redes de informação (por exemplo, a internet) também foram fontes de informação muito relevantes, com exceção da categoria de alta tecnologia no primeiro caso (pontos 6 e 14 do Gráfico 4). As redes são geralmente de fácil acesso e não possuem elevado custo de entrada. E o fato da maior parte das inovações serem novidades para a empresa (e não para o mercado) pode explicar a presença dos concorrentes como fonte de informação.

As quatro fontes de informações anteriormente mencionadas exigem menor esforço tecnológico e representam também o grau de novidade da inovação feita no Brasil, que é maciçamente formado por aprimoramentos para a empresa, e não para o mercado nacional. Vê-se que fontes de informação que poderiam levar a inovações de maior novidade são pouco exploradas (departamento de P\&D e universidades, por exemplo). Ademais, as fontes de informação que envolvem pesquisa apoiam o lançamento de produtos totalmente novos e são o foco de empresas que buscam ampliar seu market share.

A importância atribuída pelas empresas estrangeiras às informações originárias de outras empresas de seu grupo foi grande em 2003 e 2014 (Gráfico 4). Conforme apontado anteriormente, as parcerias utilizadas pelas empresas estrangeiras que cooperaram também foram baseadas em outras empresas de seu grupo. No caso das empresas nacionais, informações oriundas de outra empresa do grupo são praticamente inexistentes. Esse fato mostra uma estratégia das empresas estrangeiras de internacionalizar seus esforços inovativos no sentido de aproveitar melhor seus recursos financeiros e de conhecimento (DUNNING, 1994; FALK, 2008; CRESCENZI; GAGLIARDI; IAMMARINO, 2015). Do ponto de vista do país, por um lado, essas empresas trazem ao Brasil atualização tecnológica, mas, por outro lado, não se cria conexão com outras organizações locais para internalizar tais conhecimentos (CONSONI, 2004; CASSIOLATO; MATOS; LASTRES, 2014).

As universidades e centros de capacitação profissional só foram moderadamente consultados pelas empresas estrangeiras que cooperaram da categoria de alta tecnologia. Essas fontes de informação dependem de uma base prévia de conhecimento já estabelecida e por isso sugerem atividades mais longínquas de cooperação (CASSIMAN; VEUGELERS, 2002). Empresas nacionais e estrangeiras que cooperaram se mostraram mais adaptadas para realizar essas parcerias porque foram as que mais fizeram P\&D. 
Gráfico 4 - Fontes de informação utilizadas para inovar pela manufatura brasileira, em \% do total dos grupos de empresas, 2003 e 2014
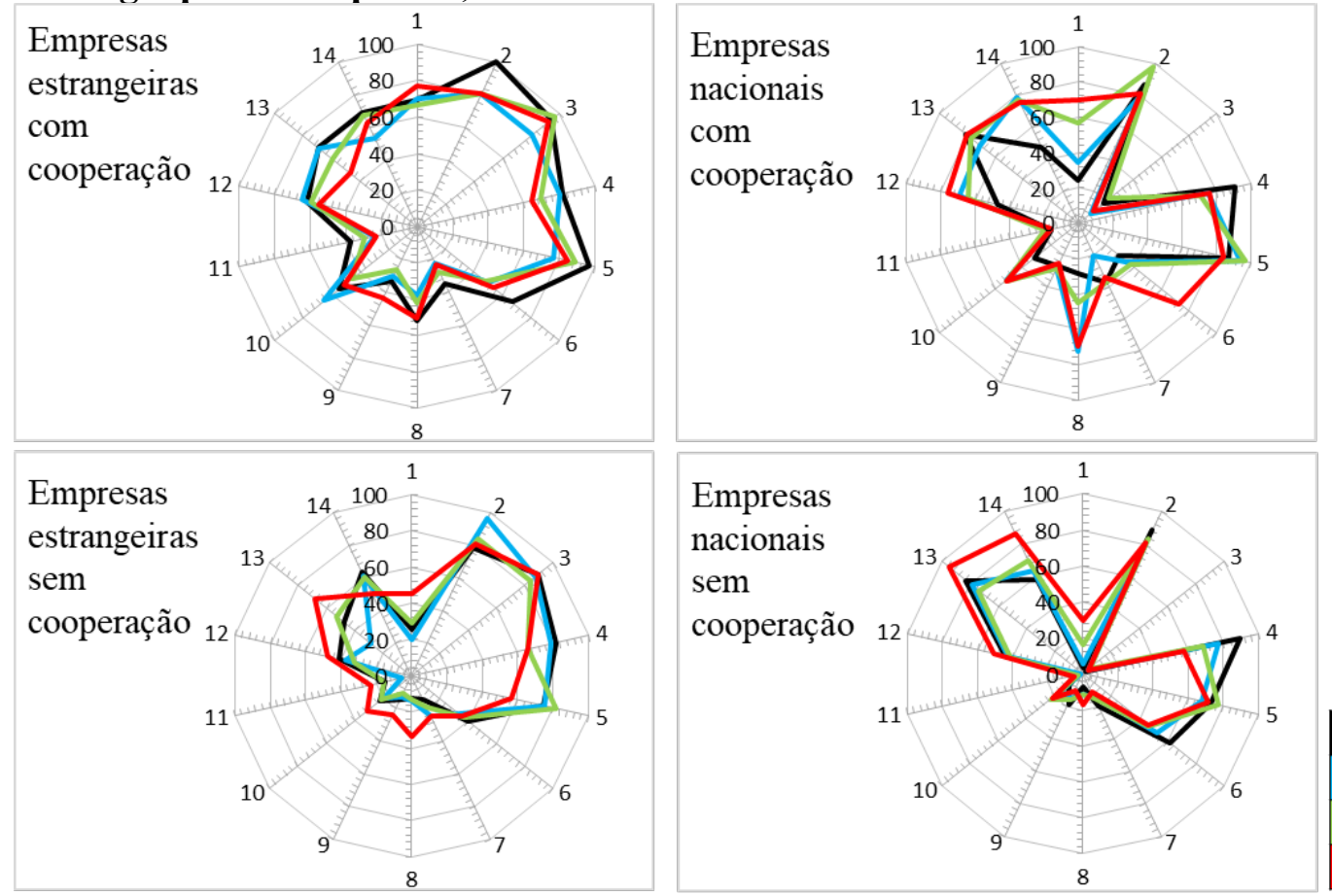

Ano: 2003
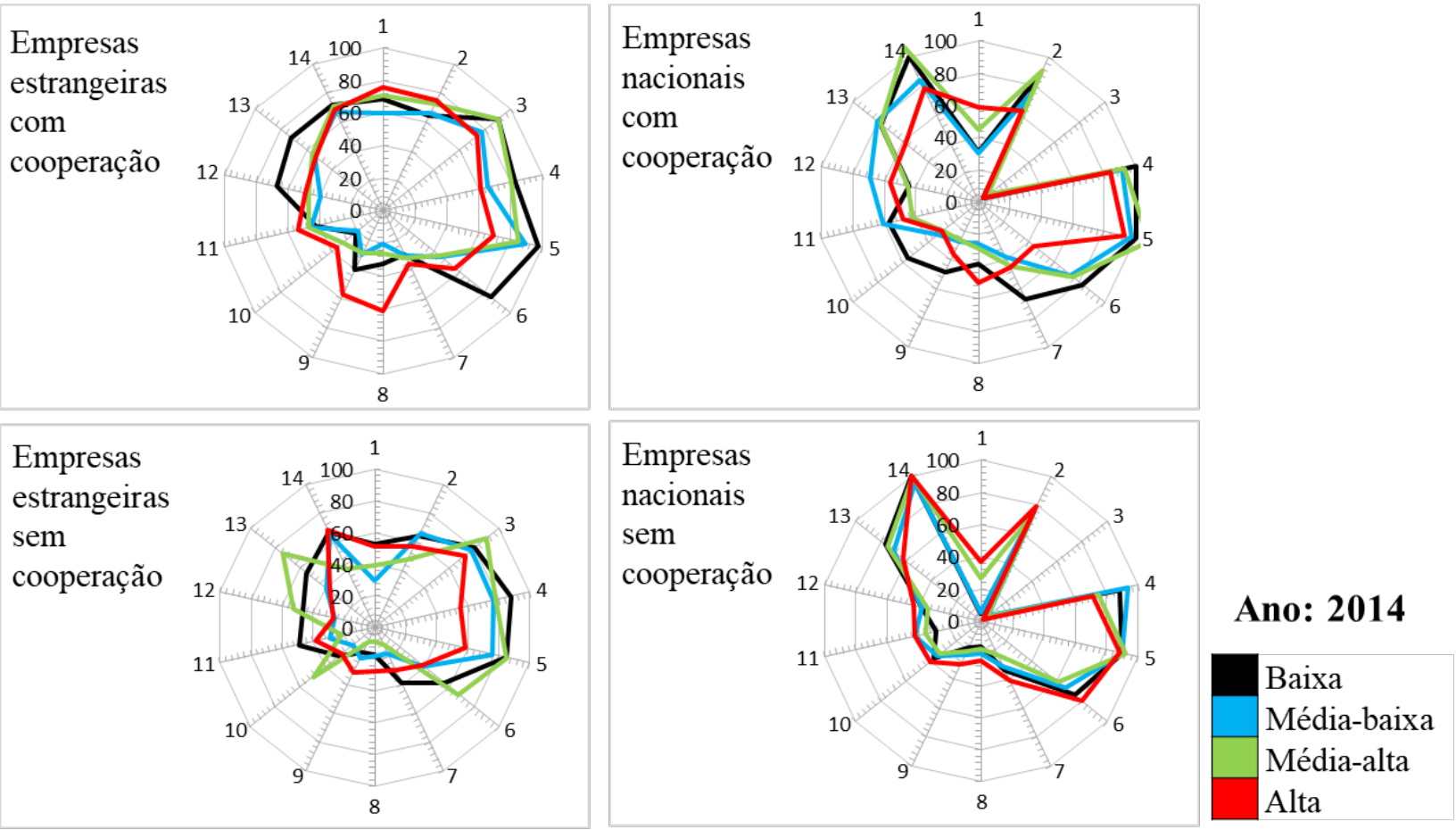

1- Departamento de P\&D

2 - Outras áreas da empresa

3 - Outra empresa do grupo

4 - Fornecedores
6 - Concorrentes

7 - Empresas de consultoria

8 - Universidades e institutos de pesquisa

9 - Centros de capacitação profissional
11 - Licenças e patentes

12 - Conferências e publicações

13 - Feiras e exposições

14 - Redes de informação

5 - Clientes ou consumidores 10 - Instituições de testes e certificações

Nota: o eixo relata o percentual de empresas em cada categoria tecnológica.

Fonte: Extração especial da PINTEC/IBGE. Cálculos e elaboração da autora. 


\subsection{Síntese dos esforços inovativos}

A Tabela 3 resume as informações a respeito do esforço inovativo realizado pelas empresas no Brasil, em 2014. As empresas inovadoras da indústria de transformação investiram $2,6 \%$ da sua receita líquida em atividades inovativas, em 2014 (Tabela 3). Como comparação, nos países da OCDE, esse percentual equivale ao destinado apenas à $\mathrm{P} \& \mathrm{D}$. Dentre as atividades inovativas, aquisição de máquinas e equipamentos para implementar produtos/processos novos ou tecnologicamente aperfeiçoados foi a principal atividade inovativa realizada com $42 \%$ dos gastos totais e a P\&D interna veem em seguida com $33 \%$. Tessarin (2018) fez um trabalho em que apresenta o tipo de atividade inovativa realizada com maior frequência por cada grupo de empresa.

Atividades internas de $\mathrm{P} \& \mathrm{D}$, aquisição de $\mathrm{P} \& \mathrm{D}$ externa e aquisição de outros conhecimentos são particularmente importantes para gerar inovações (CASSIMAN; VEUGELERS, 2002). No caso da aquisição de máquinas e equipamentos, requer-se no mínimo, uma assimilação tecnológica e treinamento para colocar a máquina em uso, o que promove um aprendizado passivo (LOS, 2000). A complexidade envolvida no processo inovativo certamente é menor, mas podemos dividi-la em dois tipos: um passivo, que permite a empresa ampliar sua produtividade via instalação de máquinas e equipamentos modernos com poucas modificações no layout produtivo e/ou nas áreas de estocagem e comercialização; e outro ativo, que exigem absorção significativa de novos conhecimentos e modificações de maior monta no funcionamento regular da empresa. Contudo, a predominância da inovação pela aquisição de máquinas e equipamentos é uma característica de firmas dominadas pelos fornecedores, que dependem do progresso tecnológico embutido nos bens de capital desenvolvidos por firmas especializadas (PAVITT, 1984).

As empresas nacionais sem cooperação para inovar buscaram, em geral, melhorar a qualidade dos produtos ao se basear em redes de informação (como a internet) e inovações de processo, essencialmente via aquisição de máquinas e equipamentos, destinando pequeno percentual da receita em P\&D.

As empresas estrangeiras que não cooperaram para inovar distinguem seu perfil entre os grupos de menor e maior intensidade tecnológica. Na média, empresas de baixa e média-baixa tecnologia tiveram um perfil parecido com as empresas nacionais sem cooperação. Por sua vez, as empresas de média-alta e alta tecnologia realizam mais $P \& D$ interna e basearam-se em informações originadas em outras empresas do grupo.

Já as empresas que cooperaram para inovar desenvolveram estratégias de inovação mais ativas e empreenderam esforços maiores para inovar. O percentual gasto tanto em P\&D como em atividades inovativas foi similar entre as empresas nacionais e estrangeiras (Tabela 3). No entanto, os esforços das empresas estrangeiras diferem de acordo com a intensidade tecnológica. Dentre as empresas de baixa e média-baixa tecnologia, as atividades inovativas basearam-se em informações de clientes e envolveram gastos com a introdução da inovação no mercado e aquisição de máquinas, para resultarem em inovações de produto. Entre as empresas de alta e média-alta tecnologia, a atividade inovativa principal foi a P\&D, a cooperação foi feita essencialmente com universidades e outra empresa do grupo localizada no exterior e as informações para inovar vieram de outra empresa do grupo ou departamento de P\&D próprio.

As empresas nacionais que cooperaram se destacam por realizarem elevados gastos com P\&D, especialmente o grupo de alta tecnologia (Tabela 3). É interessante ver que tanto o parceiro da cooperação como as fontes de informação para inovar são clientes e fornecedores, por isso o esforço teve que ser maior do que das empresas estrangeiras, pois não tinham a opção de contatar outras empresas do grupo para aproveitar informações de pesquisas já realizadas. 
Tabela 3 - Síntese dos indicadores por grupos de empresas selecionados (2014)

\begin{tabular}{|c|c|c|c|c|c|c|c|c|c|c|c|}
\hline $\begin{array}{l}\text { Grupos de } \\
\text { empresas }\end{array}$ & $\begin{array}{l}\text { Intensidade } \\
\text { tecnológica }\end{array}$ & $\begin{array}{c}\text { Receita }^{1} \\
(\%)\end{array}$ & $\begin{array}{c}\text { Receita } \\
\text { média } \\
(\mathrm{R} \$ \mathrm{mi})^{2}\end{array}$ & \begin{tabular}{|c|} 
Gasto \\
em P\&D \\
$(\mathrm{R} \$$ \\
$\mathrm{mi})^{2}$ \\
\end{tabular} & \begin{tabular}{|c|} 
Gastos em \\
P\&D / \\
Receita \\
$(\%)$ \\
\end{tabular} & $\begin{array}{c}\text { Gastos com } \\
\text { inovação / } \\
\text { Receita (\%) }\end{array}$ & $\begin{array}{c}\text { Parceiros mais } \\
\text { relevantes na } \\
\text { cooperação e local } \\
\text { de atuação }\end{array}$ & $\begin{array}{c}\text { Principais atividades } \\
\text { inovativas }\end{array}$ & $\begin{array}{l}\text { Principais fontes de informação } \\
\text { para inovar }\end{array}$ & $\begin{array}{c}\text { Tipo de } \\
\text { inovação } \\
\text { principal }\end{array}$ & $\begin{array}{l}\text { Principais impactos } \\
\text { causados pela inovação }\end{array}$ \\
\hline \multirow{5}{*}{ 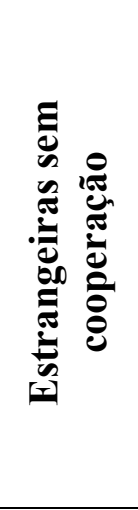 } & Baixa & 2,17 & 745,3 & 122,1 & 0,26 & 0,93 & 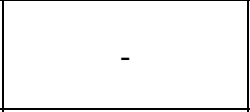 & $\begin{array}{l}\text { Aquisição de M\&E / } \\
\text { P\&D interna }\end{array}$ & $\begin{array}{l}\text { Fornecedores / Clientes / Outra } \\
\text { empresa do grupo }\end{array}$ & Processo & $\begin{array}{l}\text { Aumento da capacidade } \\
\text { produtiva / Ampliação do } \\
\text { mercado }\end{array}$ \\
\hline & Média-baixa & 0,96 & 211,0 & 130,9 & 0,62 & 4,64 & - & $\begin{array}{l}\text { Aquisição de M\&E / } \\
\text { P\&D interna }\end{array}$ & $\begin{array}{l}\text { Outra empresa do grupo / } \\
\text { Fornecedores / Clientes } \\
\end{array}$ & Processo & $\begin{array}{l}\text { Manutenção do mercado / } \\
\text { Ampliação do mercado }\end{array}$ \\
\hline & Média-alta & 5,15 & 295,8 & 986,6 & 0,87 & 2,09 & - & $\begin{array}{l}\text { P\&D interna / } \\
\text { Aquisição de M\&E }\end{array}$ & $\begin{array}{l}\text { Outra empresa do grupo / } \\
\text { Clientes / Fornecedores }\end{array}$ & Processo & $\begin{array}{l}\text { Enquadramento em } \\
\text { normas / Redução do } \\
\text { impacto ambiental }\end{array}$ \\
\hline & Alta & 1,43 & 785,7 & 304,9 & 0,97 & 1,84 & - & $\begin{array}{l}\text { P\&D interna / } \\
\text { Introdução da } \\
\text { inovação }\end{array}$ & $\begin{array}{l}\text { Outra empresa do grupo / Redes } \\
\text { de informação / Clientes }\end{array}$ & Produto & $\begin{array}{l}\text { Manutenção do mercado / } \\
\text { Melhoria na qualidade }\end{array}$ \\
\hline & Subtotal & 9,72 & 363,7 & $1.544,6$ & 0,72 & 2,05 & - & $\begin{array}{l}\text { Aquisição de M\&E / } \\
\text { P\&D interna }\end{array}$ & $\begin{array}{l}\text { Outra empresa do grupo / } \\
\text { Clientes / Fornecedores }\end{array}$ & Processo & $\begin{array}{l}\text { Manutenção do mercado / } \\
\text { Aumento da capacidade } \\
\text { produtiva }\end{array}$ \\
\hline \multirow{5}{*}{ 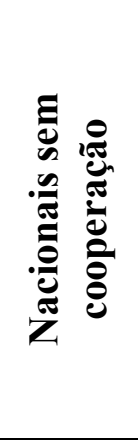 } & Baixa & 12,77 & 127,5 & 625,3 & 0,22 & 2,55 & - & $\begin{array}{l}\text { Aquisição de M\&E / } \\
\text { P\&D interna }\end{array}$ & $\begin{array}{l}\text { Redes de informação / Clientes / } \\
\text { Fornecedores }\end{array}$ & Processo & $\begin{array}{l}\text { Melhoria na qualidade / } \\
\text { Aumento da capacidade } \\
\text { produtiva }\end{array}$ \\
\hline & Média-baixa & 6,42 & 351,2 & 576,1 & 0,41 & 4,04 & - & $\begin{array}{l}\text { Aquisição de M\&E / } \\
\text { P\&D interna }\end{array}$ & $\begin{array}{l}\text { Redes de informação / } \\
\text { Fornecedores / Clientes }\end{array}$ & Processo & $\begin{array}{l}\text { Melhoria na qualidade / } \\
\text { Aumento da capacidade } \\
\text { produtiva }\end{array}$ \\
\hline & Média-alta & 5,72 & 146,6 & $1.043,4$ & 0,83 & 2,93 & - & $\begin{array}{l}\text { Aquisição de M\&E / } \\
\text { P\&D interna }\end{array}$ & $\begin{array}{l}\text { Redes de informação / Clientes / } \\
\text { Fornecedores }\end{array}$ & Processo & $\begin{array}{l}\text { Melhoria na qualidade / } \\
\text { Manutenção do mercado }\end{array}$ \\
\hline & Alta & 0,78 & 76,8 & 253,0 & 1,48 & 4,57 & - & $\begin{array}{l}\text { Aquisição de M\&E / } \\
\text { P\&D interna }\end{array}$ & $\begin{array}{l}\text { Redes de informação / Clientes / } \\
\text { Concorrentes }\end{array}$ & Processo & $\begin{array}{l}\text { Melhoria na qualidade / } \\
\text { Manutenção do mercado }\end{array}$ \\
\hline & Subtotal & 25,68 & 184,2 & $2.497,7$ & 0,44 & 3,07 & - & $\begin{array}{l}\text { Aquisição de M\&E / } \\
\text { P\&D interna }\end{array}$ & $\begin{array}{l}\text { Redes de informação / Clientes / } \\
\text { Fornecedores }\end{array}$ & Processo & $\begin{array}{l}\text { Melhoria na qualidade / } \\
\text { Manutenção do mercado }\end{array}$ \\
\hline
\end{tabular}


Tabela 3 - Síntese dos indicadores por grupos de empresas selecionados (2014)

(conclusão)

\begin{tabular}{|c|c|c|c|c|c|c|c|c|c|c|c|}
\hline $\begin{array}{l}\text { Grupos de } \\
\text { empresas }\end{array}$ & $\begin{array}{l}\text { Intensidade } \\
\text { tecnológica }\end{array}$ & $\begin{array}{c}\text { Receita }^{1} \\
(\%)\end{array}$ & $\begin{array}{l}\text { Receita } \\
\text { média } \\
(\mathrm{R} \$ \mathrm{mi})^{2}\end{array}$ & $\begin{array}{c}\text { Gasto } \\
\text { em P\&D } \\
(\mathrm{R} \$ \\
\mathrm{mi})^{2}\end{array}$ & $\begin{array}{c}\text { Gastos } \\
\text { em P\&D } \\
/ \text { Receita } \\
(\%)\end{array}$ & \begin{tabular}{|c|} 
Gastos \\
com \\
inovação / \\
Receita \\
$(\%)$ \\
\end{tabular} & $\begin{array}{c}\text { Parceiros mais relevantes } \\
\text { na cooperação e local de } \\
\text { atuação }\end{array}$ & $\begin{array}{c}\text { Principais atividades } \\
\text { inovativas }\end{array}$ & $\begin{array}{l}\text { Principais fontes de } \\
\text { informação para inovar }\end{array}$ & $\mid \begin{array}{c}\text { Tipo de } \\
\text { inovação } \\
\text { principal }\end{array}$ & $\begin{array}{c}\text { Principais impactos causados } \\
\text { pela inovação }\end{array}$ \\
\hline \multirow{5}{*}{ 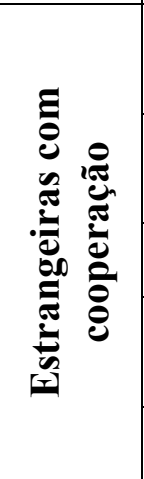 } & Baixa & 4,42 & $1.461,5$ & 241,6 & 0,25 & 2,80 & $\begin{array}{l}\text { Fornecedores / Clientes / } \\
\text { Outra empresa do grupo* }\end{array}$ & \begin{tabular}{|l} 
Introdução da \\
inovação / \\
Aquisição de M\&E
\end{tabular} & $\begin{array}{l}\text { Clientes / Outra empresa } \\
\text { do grupo / Concorrentes }\end{array}$ & Produto & $\begin{array}{l}\text { Ampliação do } \mathrm{n}^{0} \text { de produtos } \\
\text { Ampliação do mercado }\end{array}$ \\
\hline & Média-baixa & 4,07 & $1.156,2$ & 610,1 & 0,68 & 1,95 & $\begin{array}{l}\text { Outra empresa do grupo* } \\
\text { / Clientes / Fornecedores }\end{array}$ & $\begin{array}{l}\text { Aquisição de M\&E / } \\
\text { P\&D interna }\end{array}$ & $\begin{array}{l}\text { Clientes / Outra empresa } \\
\text { do grupo / Redes de } \\
\text { informação }\end{array}$ & Produto & $\begin{array}{l}\text { Manutenção do mercado / } \\
\text { Melhoria na qualidade }\end{array}$ \\
\hline & Média-alta & 13,54 & $1.361,0$ & $4.238,5$ & 1,42 & 2,99 & $\begin{array}{l}\text { Outra empresa do grupo* } \\
\text { / Fornecedores /Clientes }\end{array}$ & $\begin{array}{l}\text { P\&D interna / } \\
\text { Aquisição de M\&E }\end{array}$ & \begin{tabular}{|l|} 
Outra empresa do grupo / \\
Clientes / Fornecedores
\end{tabular} & Produto & $\begin{array}{l}\text { Melhoria na qualidade / } \\
\text { Manutenção do mercado }\end{array}$ \\
\hline & Alta & 3,22 & $1.256,3$ & 908,8 & 1,28 & 2,84 & $\begin{array}{l}\text { Universidades / Outra } \\
\text { empresa do grupo* / } \\
\text { Clientes }\end{array}$ & $\begin{array}{l}\text { P\&D interna / } \\
\text { Aquisição externa } \\
\text { de P\&D }\end{array}$ & \begin{tabular}{|l|} 
Departamento de P\&D / \\
Outras áreas da empresa / \\
Outra empresa do grupo
\end{tabular} & Processo & $\begin{array}{l}\text { Melhoria na qualidade / } \\
\text { Manutenção do mercado }\end{array}$ \\
\hline & Subtotal & 25,26 & $1.325,0$ & $5.998,9$ & 1,08 & 2,77 & \begin{tabular}{|l|} 
Outra empresa do grupo* \\
/ Clientes / Fornecedores \\
\end{tabular} & $\begin{array}{l}\text { P\&D interna / } \\
\text { Aquisição de M\&E }\end{array}$ & $\begin{array}{l}\text { Clientes / Outra empresa } \\
\text { do grupo / Fornecedores }\end{array}$ & Produto & $\begin{array}{l}\text { Melhoria na qualidade / } \\
\text { Manutenção do mercado }\end{array}$ \\
\hline \multirow{5}{*}{ 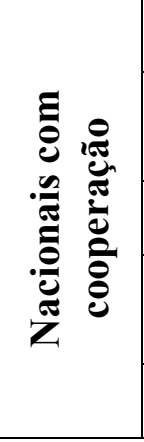 } & Baixa & 11,33 & 127,5 & $1.148,0$ & 0,46 & 2,47 & $\begin{array}{l}\text { Fornecedores / Clientes / } \\
\text { Consultorias }\end{array}$ & $\begin{array}{l}\text { Aquisição de M\&E / } \\
\text { P\&D interna }\end{array}$ & $\begin{array}{l}\text { Fornecedores / Clientes / } \\
\text { Outras áreas da empresa }\end{array}$ & Processo & $\begin{array}{l}\text { Melhoria na qualidade / } \\
\text { Manutenção do mercado }\end{array}$ \\
\hline & Média-baixa & 18,86 & 351,2 & $3.517,7$ & 0,85 & 1,77 & $\begin{array}{l}\text { Clientes / Fornecedores / } \\
\text { Consultorias }\end{array}$ & $\begin{array}{l}\text { P\&D interna / } \\
\text { Aquisição de M\&E }\end{array}$ & $\begin{array}{l}\text { Clientes / Fornecedores / } \\
\text { Redes de informação }\end{array}$ & Processo & $\begin{array}{l}\text { Melhoria na qualidade / } \\
\text { Aumento da capacidade } \\
\text { produtiva }\end{array}$ \\
\hline & Média-alta & 7,76 & 146,6 & $2.381,6$ & 1,40 & 2,84 & $\begin{array}{l}\text { Clientes / Fornecedores / } \\
\text { Concorrentes }\end{array}$ & $\begin{array}{l}\text { P\&D interna / } \\
\text { Aquisição de M\&E }\end{array}$ & $\begin{array}{l}\text { Clientes / Redes de } \\
\text { informação/ Fornecedores }\end{array}$ & Processo & $\begin{array}{l}\text { Melhoria na qualidade / } \\
\text { Manutenção do mercado }\end{array}$ \\
\hline & Alta & 1,38 & 76,8 & $1.709,3$ & 5,63 & 8,18 & $\begin{array}{l}\text { Fornecedores / Clientes / } \\
\text { Universidades }\end{array}$ & $\begin{array}{l}\text { P\&D interna / } \\
\text { Aquisição externa } \\
\text { de P\&D }\end{array}$ & $\begin{array}{l}\text { Clientes / Fornecedores / } \\
\text { Redes de informação }\end{array}$ & Processo & $\begin{array}{l}\text { Melhoria na qualidade / } \\
\text { Enquadramento em normas }\end{array}$ \\
\hline & Subtotal & 39,34 & 184,2 & $8.756,7$ & 1,01 & 2,41 & $\begin{array}{l}\text { Fornecedores / Clientes / } \\
\text { Consultoria }\end{array}$ & $\begin{array}{l}\text { P\&D interna / } \\
\text { Aquisição de M\&E }\end{array}$ & \begin{tabular}{|l|} 
Clientes / Redes de \\
informação/ Fornecedores
\end{tabular} & Processo & $\begin{array}{l}\text { Melhoria na qualidade / } \\
\text { Manutenção do mercado }\end{array}$ \\
\hline \multicolumn{2}{|c|}{$\begin{array}{l}\text { Empresas com } \\
\text { cooperação }\end{array}$} & 64,60 & 277,7 & $14.755,6$ & 1,04 & 2,51 & $\begin{array}{l}\text { Clientes / Fornecedores / } \\
\text { Universidades }\end{array}$ & $\begin{array}{l}\text { Aquisição de M\&E / } \\
\text { P\&D interna }\end{array}$ & $\begin{array}{l}\text { Clientes / Outras áreas da } \\
\text { empresa / Fornecedores }\end{array}$ & Produto & $\begin{array}{l}\text { Melhoria na qualidade / } \\
\text { Manutenção do mercado }\end{array}$ \\
\hline \multicolumn{2}{|c|}{$\begin{array}{l}\text { Empresas sem } \\
\text { cooperação }\end{array}$} & 35,40 & 27,7 & $4.042,3$ & 0,52 & 2,68 & 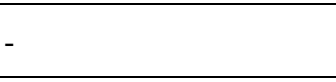 & $\begin{array}{l}\text { Aquisição de M\&E / } \\
\text { Projeto industrial }\end{array}$ & \begin{tabular}{|l|} 
Outras áreas da empresa / \\
Fornecedores / Clientes
\end{tabular} & Processo & $\begin{array}{l}\text { Manutenção do mercado / } \\
\text { Melhoria na qualidade }\end{array}$ \\
\hline \multicolumn{2}{|c|}{$\begin{array}{l}\text { Indústria de } \\
\text { transformação }\end{array}$} & 100,00 & 66,2 & $18.797,9$ & 0,86 & 2,57 & $\begin{array}{l}\text { Clientes / Fornecedores / } \\
\text { Universidades }\end{array}$ & $\begin{array}{l}\text { Aquisição de M\&E / } \\
\text { P\&D interna }\end{array}$ & $\begin{array}{l}\text { Outras áreas da empresa / } \\
\text { Clientes / Fornecedores }\end{array}$ & Processo & $\begin{array}{l}\text { Melhoria na qualidade / } \\
\text { Manutenção do mercado }\end{array}$ \\
\hline
\end{tabular}

Nota: ${ }^{1}$ Receita Líquida de Vendas. ${ }^{2}$ Valores em Reais a preços de $2016 .{ }^{*}$ Indica que o parceiro na cooperação está localizado no exterior.

Fonte: Pintec 2014 / IBGE. Elaborado pela autora. 


\section{Conclusões}

Este trabalho explorou uma tabulação especial da Pintec para os períodos de 2001-2003 e 20122014 das empresas manufatureiras inovadoras com e sem relação de cooperação para inovar, por origem do capital e intensidade tecnológica. Ele contribui com a literatura ao apresentar uma seleção de dados inédita e avaliar todos os parceiros da cooperação para inovar, não apenas universidades e institutos de pesquisa, como é predominante no Brasil.

O número de empresas inovadoras da indústria de transformação brasileira se manteve estagnado entre 2003 e 2014. Verificou-se que não há uma diferença significativa nos esforços inovativos das empresas a partir da origem do capital, no entanto, há uma diferença substantiva a favor das empresas que cooperaram para inovar frente às que não cooperaram. As empresas que inovaram sem relação de cooperação (cinco sextos das inovadoras), sejam de controle do capital nacional ou estrangeiro, basearam suas atividades inovativas em agentes externos à empresa. As inovações foram introduzidas a partir de informações obtidas com fornecedores, clientes e redes de informação e os gastos inovativos concentraram-se na aquisição de máquinas e equipamentos. Essas empresas seguiram uma trajetória de inovação menos arriscada, baseada na manutenção do market share; assim, seu esforço inovativo e desempenho inovador foram limitados comparativamente às empresas que inovaram com cooperação.

O subconjunto de empresas que cooperaram para inovar reuniu quase dois terços da receita líquida de vendas e dos gastos com atividades inovativas das empresas inovadoras, embora representassem apenas um sexto das empresas. Por isso, as empresas que inovaram com cooperação representam uma ilha de excelência no universo das empresas inovadoras brasileiras. Elas realizaram mais atividades inovativas (relativamente às que não cooperaram) e ainda mostraram-se mais aptas a atividades de longo prazo, como a P\&D interna, e se mostraram habilitadas para se conectarem com instituições externas de modo a internalizar conhecimentos e tecnologias. As empresas de controle nacional fizeram um esforço inovativo similar ao das empresas estrangeiras, embora não tivessem a opção de acessar outras empresas do grupo para utilizar informações para inovar, como fazem as estrangeiras instaladas no Brasil. Como resultado, além de manter a parcela de mercado, as inovações produziram melhorias nos produtos.

Quanto às empresas estrangeiras que cooperaram, além de se basearem fortemente em outras empresas do seu grupo no exterior para inovar - no que se refere tanto a fontes de informação como a parceiros nas cooperações -, elas empreenderam no Brasil esforços tecnológicos menores do que os efetivados em outros países nos quais atuam. Assim, pode-se concluir que a atividade inovativa realizada por elas foi do tipo adaptativa, ou seja, aproveitam o grande mercado brasileiro para adequar descobertas feitas fora do Brasil às características da demanda local sem necessariamente produzir esforço significativo para gerar capacitação tecnológica doméstica. Esse perfil adaptativo é mencionado pela literatura, no entanto, as evidências eram restritas a estudos de caso. Este estudo exibiu evidências empíricas de que esse perfil adaptativo é generalizado setorialmente no Brasil.

Quanto as empresas nacionais, as relações de cooperação para todas as categorias tecnológicas envolveram principalmente parceiros com quem a empresa mantém relação produtiva direta (clientes e fornecedores) e, apenas as de alta tecnologia utilizaram moderadamente a cooperação com universidades e institutos de pesquisa. Por fim, a cooperação com outra empresa do grupo foi muito pouco frequente entre as empresas de controle do capital nacional de qualquer categoria tecnológica.

\section{Referências}

ABRAMOVSKY, L.; KREMP, E.; LÓPEZ, A.; SCHMIDT, T.; SIMPSON, H. Understanding cooperative innovative activity: evidence from four European countries. Economics of Innovation and New Technology, v. 18, n. 3, p. 243-265, abr. 2009.

AGHION, P.; HOWITT, P. A model of growth through creative destruction. NBER Working Paper, $\mathrm{n}$. $3223,1990$.

ARROW, K. J. The economic implications of learning by doing. The Quarterly Journal of Economics, v. 29, n. 3, p. 155-173, 1962.

BASTOS, C. P.; BRITTO, J. Inovação e geração de conhecimento científico e tecnológico no Brasil: uma análise dos dados de cooperação da Pintec segundo porte e origem de capital. Revista Brasileira de Inovação, v. 16, n. 1, p. 35-62, 2017. 
BELL, M. "Learning" and the Accumulation of Industrial Technological Capacity in Developing Countries. In: FRANSMAN, M.; KING, K. (Ed.). Technological Capability in the Third World. London: Palgrave Macmillan, 1984.

BRESCHI, S.; MALERBA, F. Sectoral innovation systems: technological regimes, Schumpeterian dynamics, and spatial boundaries. In: EDQUIST, C. (Ed.). Systems of Innovation: Technologies, Institutions and Organizations. London: Pinter A Cassell, 1997.

CASSIMAN, B.; VEUGELERS, R. R\&D cooperation and spillovers: some empirical evidence from Belgium. American Economic Review, v. 92, n. 4, p. 1169-1184, 2002.

CASSIOLATO, J. E.; BRITTO, J.; VARGAS, M. A. Arranjos cooperativos e inovação na indústria brasileira. In: DE NEGRI, J. A.; SALERNO, M. S. (Ed.). Inovações, padrões tecnológicos e desempenho das firmas industriais brasileiras. Brasília: IPEA, 2005.

CASSIOLATO, J. E.; LASTRES, H. M. M. Políticas de inovação e desenvolvimento. In: COUTINHO, D. R.; FOSS, M. C.; MOUALLEM, P. S. B. (Ed.). Inovação no Brasil: avanços e desafios jurídicos e institucionais. Rio de Janeiro: Editora Blucher, 2017.

CASSIOLATO, J. E.; MATOS, M. P. de; LASTRES, H. M. M. Empresas transnacionais e o desenvolvimento tecnológico brasileiro. Rio de Janeiro: E-Papers, 2014.

COHEN, W. M.; LEVINTHAL, D. A. Absorptive capacity: a new perspective on learning and innovation. Administrative Science Quarterly, v. 35, n. 1, p. 128-152, 1990.

COHEN, W. M.; NELSON, R. R.; WALSH, J. P. Links and impacts: the influence of public research on industrial R\&D. Management Science, v. 48, n. 1, p. 1-23, 2002.

CONSONI, F. L. Da tropicalização ao projeto de veículos: um estudo das competências em desenvolvimento de produtos nas montadoras de automóveis no Brasil. 2004. Universidade Estadual de Campinas, 2004.

CRESCENZI, R.; GAGLIARDI, L.; IAMMARINO, S. Foreign multinationals and domestic innovation: Intra-industry effects and firm heterogeneity. Research Policy, v. 44, n. 3, p. 596-609, 2015.

DOSI, G.; PAVITT, K.; SOETE, L. The economics of technical change and international trade. New York: New York University Press, 1990.

DUNNING, J. H. Multinational enterprises and the globalization of innovatory capacity. Research Policy, v. 23, n. 1, p. 67-88, 1994.

FALK, M. Effects of foreign ownership on innovation activities: empirical evidence for twelve European countries. National Institute Economic Review, v. 204, n.1, p.85-97, 2008.

FARIA, P. de; LIMA, F.; SANTOS, R. Cooperation in innovation activities: The importance of partners. Research Policy, v. 39, n. 8, p. 1082-1092, out. 2010.

FERNANDES, A. C. A.; DE SOUZA, B. C.; DA SILVA, A. S.; SUZIGAN, W.; CHAVES, C. V; ALBUQUERQUE, E. D. M. E. Academy-industry links in Brazil: evidence about channels and benefits for firms and researchers. Science and Public Policy, v. 37, n. 7, p. 485-498, 2010.

GUADALUPE, M.; KUZMINA, O.; THOMAS, C. Innovation and foreign ownership. American Economic Review, v. 102, n. 7, p. 3594-3627, dez. 2012.

IBGE. Pesquisa Industrial de Inovação Tecnológica - Série Relatórios Metodológicos. 30. ed. Rio de Janeiro: IBGE, 2004.

IBGE. Pesquisa Industrial de Inovação Tecnológica 2003. Rio de Janeiro: IBGE, 2005.

IBGE. Pesquisa de Inovação 2014. Rio de Janeiro: IBGE, 2016.

JIMÉNEZ-JIMÉNEZ, D.; MARTÍNEZ-COSTA, M.; SANZ-VALLE, R. Knowledge management practices for innovation: a multinational corporation's perspective. Journal of Knowledge Management, v. 18, n. 5, p. 905-918, 2014.

KANNEBLEY JUNIOR, S.; PORTO, G. S.; PAZELLO, E. T. Inovação na indústria brasileira: uma análise exploratória a partir da Pintec. Revista Brasileira de Inovação, v. 3, n. 1, p. 87-128, 2004.

KLEVORICK, A. K.; LEVIN, R. C.; NELSON, R. R.; WINTER, S. G. On the sources and significance of interindustry differences in technological opportunities. Research Policy, v.24, n.2, p. 185-205, 1995. KLINE, S. J.; ROSENBERG, N. An overview of innovation. In: LANDAU, R.; ROSENBERG, N. (Ed.). The positive sum strategy. Washington: National Academy of Press, 1986.

KOELLER, P. Dinâmica da inovação: Brasil frente aos países da União Europeia (indícios de 2014). 
Texto para discussão IPEA, n. 2371, 2018.

LALL, S. Technological capabilities and industrialization. World Development, v.20, n.2, p.165-186, 1992.

LALL, S. The technological structure and performance of developing country manufactured exports, 1985-98. Oxford Development Studies, v. 28, n. 3, p. 337-369, 2000.

LEVIN, R. C.; KLEVORICK, A. K.; NELSON, R. R.; WINTER, S. G. Appropriating the returns from and industrial research and development. Brookings Papers on Economic Activity, v. 3, n. Special Issue on Microeconomics, p. 783-831, 1987.

LOS, B. The empirical performance of a new inter-industry technology spillover measure. In: SAVIOTTI, P. P.; NOOTEBOOM, B. (Ed.). Technology and Knowledge: from the firm to innovation systems. London: dward Elgar Publishing, 2000.

LUNDVALL, B.- $\AA$. National Systems of Innovation: towards a theory of innovation and interactive learning. London: Pinter, 1992.

MORCEIRO, P. C. Evolution and sectoral competiveness of the Brazilian manufacturing industry. In: AMANN, E.; AZZONI, C. R.; BAER, W. (Ed.). The Oxford Handbook of the Brazilian Economy. New York: Oxford University Press, 2018.

OECD. Internationalisation of industrial R\&D: patterns and trends. Paris: OECD Publishing, 1998. OECD. OECD Science, Technology and Innovation Outlook 2016. Paris: OECD Publishing, 2016.

OECD. OECD Science, Technology and Industry Scoreboard 2017: The digital transformation. Paris: OECD Publishing, 2017.

PAVITT, K. Sectoral patterns of technical change: Towards a taxonomy and a theory. Research Policy, v. 13, p. 343-373, 1984.

QUEIROZ, S.; CARVALHO, R. de Q. Empresas multinacionais e inovação tecnológica no Brasil. São Paulo em Perspectiva, v. 19, n. 2, p. 51-59, jun. 2005.

RAMA, R. Foreign investment innovation: a review of selected policies. The Journal of Technology Transfer, v. 33, n. 4, p. 353-363, 2008.

RAPINI, M. S. Interação universidade-empresa no Brasil: evidências do Diretório dos Grupos de Pesquisa do CNPq. Revista Estudos Econômicos, v. 37, n. 1, p. 211-233, 2007.

SÁNCHEZ, A. G.; MOLERO, J.; RAMA, R. Are "the best" foreign subsidiaries cooperating for innovation with local partners? The case of an intermediate country. Science and Public Policy, v. 43, n. 4, p. 532-545, 2016.

SCHUMPETER, J. A. The theory of economic development. New York: Oxford University, 1911.

SCHUMPETER, J. A. Capitalism, socialism \& democracy. London and New York: Routledge, 1942. SUZIGAN, W.; ALBUQUERQUE, E. D. M. E. A interação entre universidades e empresas em perspectiva histórica no Brasil. In: SUZIGAN, W.; ALBUQUERQUE, E.; CARIO, S. (Ed.). Em busca da inovação: a interação universidade-empresa no Brasil. Belo Horizonte: Editora Autêntica, 2011. SUZIGAN, W.; ALBUQUERQUE, E.; GARCIA, R.; RAPINI, M. S. University and industry linkages in Brazil: some preliminary and descriptive results. Seoul Journal of Economics, v. 22, n. 4, p. 591$611,2009$.

TEECE, D. J. Capturing value from knowledge assets: the new economy, markets for know-how, and intagible assets. California Management Review, v. 40, n. 3, p. 55-79, 1998.

TESSARIN, M. S. Cooperação e inovação tecnológica na indústria brasileira: uma análise comparativa entre empresas interativas e não interativas. 2012. Dissertação (Mestrado) - Instituto de Geociências, Universidade Estadual de Campinas, Campinas, 2012.

TESSARIN, M. S. O papel da inovação, diversificação e vizinhança setorial no desenvolvimento industrial recente do Brasil. 2018. Tese (Doutorado) - Faculdade de Economia, Administração e Contabilidade, Universidade de São Paulo, São Paulo, 2018.

TETHER, B. S. Who co-operates for innovation, and why. Research Policy, v.31, n.6, p. 947-967, 2002. VEUGELERS, R. Internal R\&D expenditures and external technology scouting. Research Policy, v. 26, p. 303-315, 1997.

ZUNIGA, P.; DE NEGRI, F.; DUTZ, M. A.; PILAT, D.; RAUEN, A. Conditions for innovation in Brazil: a review of key issues and policy challenges. IPEA Discussion Paper, n. 218, p. 1-102, 2016. 